\title{
"HOW CAN I RECONCILE WITH YOU WHEN YOUR FOOT IS ON MY NECK?": THE ROLE OF JUSTICE IN THE PURSUIT OF TRUTH AND RECONCILIATION
}

\author{
Olwyn Conway*
}

2018 MICH. ST. L. REV. 1349

TABLE OF CONTENTS

INTRODUCTION

I. COMBINING INFORMAL AND FORMAL JUSTICE

MECHANISMS MAY ACHIEVE BETTER OUTCOMES FOR

VICTIMS, OFFENDERS, AND SOCIETY

A. Perpetrator Denial May Thwart Informal Justice Practices

B. The Formal Justice System is Uniquely Equipped to Overcome Denial of Wrongdoing

C. The Formal Justice System Oversimplifies Both Harms and Parties, Making It Incapable of Meaningfully Addressing Systemic Injustice

D. Neither a Formal Retributive Justice System nor Informal Restorative Justice Practices Are Sufficient to Bring About Reconciliation

II. PROSECUTOR DEPENDENCY ON POLICE WITNESSES BREEDS COMPLICITY WITH POLICE MISCONDUCT

A. Police Perjury Is Common and Prosecutors

* Assistant Clinical Professor of Law, The Ohio State University Moritz College of Law. Thank you to the Michigan State University College of Law for the opportunity to present this paper at the Spring 2018 Symposium, Is It Time for Truth and Reconciliation in Post-Ferguson America? Thank you to the junior faculty at The Ohio State University Moritz College of Law for their insights, and especially to Amna Akbar, Mohamed Helal, and Anne Ralph for their thoughtful contributions. I am also incredibly grateful to Amy Laura Cahn, Ingrid Mattson, Deborah Jones Merritt, my true partner-in-crime, for her invaluable feedback, and to Matthew Finston for his excellent research assistance. This paper benefitted tremendously from the work of the editors of the Michigan State Law Review. All errors are my own.

1. Greensboro Truth \& ReCOnCILIATIOn COMm'N, Greensboro Truth and Reconciliation Commission Final Report: Introduction 19 (2006), http://www.greensborotrc.org/introduction.pdf

[https://perma.cc/SPF3-SNJL] [hereinafter Greensboro TRC Report] (quoting Archbishop Desmond Tutu). 
Are-Knowingly or Unknowingly - Complicit

B. Prosecutors Rarely Allege Officer Misconduct

Because They Rely on Police Officers as Witnesses..... 1375

C. Police Claims of Self-Defense to Justify Deadly Force Implicate Narratives of Black Criminality and Dangerousness.

D. Pro-Police Narratives Hurt Prosecutors When

Prosecuting Police.

III. More Restorative Prosecution Practices Could

DECREASE RELIANCE ON POLICE TESTIMONY, INCREASE DIVERSITY OF NARRATIVES IN THE PUBLIC SPHERE, AND IMPROVE PROSECUTION OF OFFICER MISCONDUCT.

A. Shifting to Restorative-Driven Decision-Making Would Encourage Prosecutors to Act as ProblemSolvers as Opposed to Adversaries

B. Electing Progressive Prosecutors Should Include Electing Prosecutors Committed to Restorative Justice.

C. Training and Educating Progressive Prosecutors Can Support This Paradigmatic Shift.

\section{INTRODUCTION}

In Ferguson, a wound bleeds. For 108 days, we have been in a state of prolonged and protracted grief. . . . We have had no choice but to cling together in hope, faith, love and indomitable determination to capture that ever-escaping reality of justice ... we find ourselves reinjured, continually heartbroken, and robbed of even the remote possibility of judicial resolution. For 108 days, we have continuously been admonished that we should "let the system work," and wait to see what the results are. The results are in. And we still don't have justice. . . We, altogether, bound up in a system that continues to treat some men better than others. A system that preserves some and disregards others. A system that protects the rights of some and does not guard the rights of all. And until this system is dismantled, until the status quo that deems us less valuable than others is no longer acceptable or profitable, we will struggle. ${ }^{2}$

2. Dmckesso, The Results Are In: An Open Letter from Protestors on the Grand Jury Decision, SCRIBD (Nov. 25, 2014), https://www.scribd.com/ document/248115932/The-Results-Are-in-Open-Letter-11-24-14 [https://perma.cc/RTB7-GXPE] (emphasis added). 
The residents of Ferguson, Missouri may someday seek reconciliation. Yet, in the wake of the death of Mike Brown, and in the half-year spent waiting for the slow wheels of the criminal system to turn, Ferguson did not ask for reconciliation; it sought justice. Citizens across the country reeling from the shooting of unarmed members of their community have echoed this demand. Cleveland demanded justice for the killings of Malissa Williams, Timothy Russell, and Tamir Rice; ${ }^{3}$ Baton Rouge demanded justice for the killing of Alton Sterling; ${ }^{4}$ Minnesota demanded justice for the killing of Philando Castile. ${ }^{5}$ The list, tragically, goes on. ${ }^{6}$ American communities recovering from the wounds of loss of life- particularly when those wounds are tinged with the pain of racial animus - want justice before reconciliation. ${ }^{7}$

3. Daniel McGraw, Cleveland Officer Not Guilty Over Deaths of Two People Shot at 137 Times by Police, GuARdian (May 23, 2015, 1:45 PM), https://www.theguardian.com/us-news/2015/may/23/cleveland-officer-not-guiltyshot-137-times-police [https://perma.cc/7H2E-PTNA]; Mitch Smith \& Ashley Southall, Cleveland Officer Acquitted of Manslaughter in 2012 Deaths, N.Y. TIMES (May 23, 2015), https://www.nytimes.com/2015/05/24/us/michael-brelo-clevelandpolice-officer-acquitted-of-manslaughter-in-2012-deaths.html

[https://perma.cc/PW8Q-FVHV]; Timothy Williams \& Mitch Smith, Cleveland Officer Will Not Face Charges in Tamir Rice Shooting Death, N.Y. TIMES (Dec. 28, 2015), https://www.nytimes.com/2015/12/29/us/tamir-rice-police-shootiingcleveland.html [https://perma.cc/BH55-PX9G].

4. Jason Hanna, No Charges Against Officers in Alton Sterling Death; Other Videos are Coming, CNN (Mar. 27, 2018, 6:22 PM), https://www.cnn.com/ 2018/03/27/us/alton-sterling-investigation/index.html [https://perma.cc/42AD9ZTJ].

5. Mitch Smith, Minnesota Officer Acquitted in Killing of Philando Castile, N.Y. Times (June 16, 2017). Valerie, Castile's mother, proclaimed that "[t]he system in this country continues to fail black people and will continue to fail us." Id.

6. See Eugene Scott, Police Shootings of Unarmed Black People Have Not Ended. But Top-Level Political Conversations About Them Have., Wash. Post (Mar. 22, 2018), https://www.washingtonpost.com/news/the-fix/wp/2018/03/22/ police-shootings-of-unarmed-black-people-have-not-ended-but-top-level-politicalconversations-about-them-have/?utm term $=.637 \mathrm{bbbe} 196 \mathrm{cf}$ [https://perma.cc/RR8BA34V. See also I. Bennett Capers, Crime, Legitimacy, and Testilying, 83 IND. L.J. 835, 844-45 (2008) (recounting the police assaults of Rodney King in Los Angeles, Arthur McDuffie in Miami, Nathaniel Jones in Cincinnati, Robert Davis in New Orleans, and Amadou Diallo and Sean Bell in New York).

7. Jin Hee Lee \& Sherrilyn A. Ifill, Do Black Lives Matter to the Courts?, in Policing the Black Man 274 (Angela Davis ed., 2017) ("One of the most frequently articulated frustrations of the black community is the lack of accountability for police abuse, especially for the unjustified killings of black individuals. ... [T] he conviction of individual police officers would offer some vindication for the widespread misconduct faced by communities of color at the hands of police departments as a whole."). 
To ignore these calls by pursuing informal justice practices in lieu of criminal prosecutions would likely undermine the objectives of reconciliation. It would reinforce the double standard citizens perceive when police officers are not charged with misconduct. ${ }^{8}$ Officers are rarely subject to sanction for their misconduct-whether that misconduct be falsification of evidence or acts of brutality. ${ }^{9}$ In the rare instances when action is taken, police are shielded by protections not typically available to others in the criminal system. ${ }^{10}$ This double standard is especially present when comparing the treatment of police to those most disproportionately ensnared in the criminal system: lowincome men of color. ${ }^{11}$ Moreover, the United States has a long legacy of state-sanctioned violence against people of color ${ }^{12}$ that feeds the culture of impunity surrounding police brutality. ${ }^{13}$ Asking citizens who are being systematically oppressed to reconcile with their oppressors is unacceptable unless society simultaneously works to end that oppression. ${ }^{14}$ Yet prosecutors are consistently unwilling or unable

8. See id. at 258-259; see also id. at 279-80 ("When it comes to prosecutions of police officers accused of killing black victims . . . there is a legitimate concern about the existence of a double standard with respect to how much evidence establishes a reasonable doubt and how much of a presumption of innocence officers receive, as compared to the black criminal defendants who come from the same communities as the black victims of police abuse.").

9. See Police Violence Map, Mapping Police Violence, https://mappingpoliceviolence.org [https://perma.cc/3EFY-MCVE] (last visited Feb. $17,2019)$. In $2015,99 \%$ of cases in which police shot and killed civilians resulted in no convictions. $I d$. In the vast majority of these cases, the offending officers were not even charged with a crime. Id. See also Fatal Force: Police Shootings 2016 Database, WASH. POST, https://www.washingtonpost.com/graphics/national/police-shootings2016/ [https://perma.cc/T3VR-37E6] (last visited Mar. 4, 2019) (noting that of the 963 cases of people being shot and killed by police in 2016 only thirteen resulted in charges of murder or manslaughter).

10. See Kate Levine, How We Prosecute the Police, 104 Geo. L.J. 745, 755$56(2016)$.

11. See Capers, supra note 6 , at 874 ; see also Levine, supra note 10 , at 755 56.

12. Lee \& Ifill, supra note 7, at 255-56 ("The undeniable truth is that black men, women and children have long been the victims of state violence. Governmentsanctioned slavery, which took the lives of millions of Africans forced into servitude, gave way to a government-sanctioned convict leasing system and lynchings during the Jim Crow era."). The same is true for other people of color in the United States who have all also been targeted at various times throughout the nation's history for both higher incidents of violence and lower degrees of protection by the State.

13. Capers, supra note 6.

14. Greensboro TRC Report, supra note 1, at 19. It is for this reason that this Article is titled using the words of Archbishop Desmond Tutu: "How can I reconcile with you when your foot is on my neck?" 
to secure justice for victims of police violence. ${ }^{15}$ Until the American criminal justice system addresses this justice imbalance that holds police officers to a lower standard than the communities they police, meaningful reconciliation is impossible.

This Article offers a unique reform proposal to address the systemic causes of this two-tiered justice system. Rather than foregoing the formal criminal system for informal justice practices in the case of police shootings, ${ }^{16}$ the formal justice system, as a whole, needs to be made more restorative. Many prosecutors are currently unable or unwilling to bring charges or seek convictions against police officers because they are dependent on officer cooperation to make out their cases. This dependency can cause prosecutors to rely on officer narratives in charging decisions and trial strategy, even when those narratives are problematic, biased, or false. A shift to a more restorative criminal system would decrease prosecutor reliance on officers and therefore decrease the degree to which prosecutors are complicit in officer perjury. It may also increase a prosecutor's ability to dispel pro-police narratives in prosecutions of police misconduct. As prosecutors are increasingly willing to bring charges against officers and increasingly successful in securing convictions when warranted, they will be serving their core function to condemn

15. See Police Violence Map, supra note 9. See also Angela Davis, Introduction to Policing THE BLACK MAN: ARREST, PROSECUTION, AND IMPRISONMENT xi-xii (Angela Davis ed., 2017). An analysis done by The Washington Post and Bowling Green State University indicated that since 2005, out of thousands of fatal shootings by law enforcement, only fifty-four officers have been charged with or indicted for a crime resulting from the shootings. See Kimberly Kindy \& Kimbriell Kelly, Thousands Dead, Few Prosecuted, WASH. Post (Apr. 11, 2015), https://www.washingtonpost.com/sf/investigative/2015/04/11/thousands-dead-fewprosecuted/?noredirect $=$ on\&utm_term $=.164 \mathrm{c} 68493 \mathrm{~d} 19 \quad[\mathrm{https}: / /$ perma.cc/TC4MXLNE].

16. See Jill E. Williams, Legitimacy and Effectiveness of a Grassroots Truth and Reconciliation Commission, 72 L. \& ConTEMP. ProBS. 143, 143 (2009). Informal justice practices were used in Greensboro, North Carolina following the failed prosecution of $\mathrm{Ku}$ Klux Klan members who shot and killed five demonstrators at a "Death to the Klan" rally in 1979. See id. at 144. Decades later, Greensboro held one of the few Truth and Reconciliation Commissions convened in the United States. See $i d$. at 144-45. However, its results were mixed and the Executive Director herself has recognized that many believe the City is just as divided after the Commission as it was before. See id. at 148. Similarly, the truth commission convened in the wake of Chicago's police torture scandal was criticized as "less a vehicle for truth-seeking, and more a Hail-Mary play for state prisoners who have long since exhausted all other types of formal judicial relief." See Kim D. Chanbonpin, Truth Stories: Credibility Determinations at the Illinois Torture Inquiry and Relief Commission, 45 LOY. U. CHI. L.J. 1085, 1088 (2014). 
wrongdoing and uphold our societal values by protecting all citizens from violence and harm.

Part I raises some of the criticisms of informal justice systems when used in lieu of formal prosecutions. It then addresses some of the shortcomings of the American criminal system's focus on retribution over rehabilitation and restoration. ${ }^{17}$ This Part then addresses some of the ways informal restorative practices, used alongside the formal justice system, could improve outcomes and stakeholder satisfaction.

Next, Part II argues that prosecutorial dependence on police testimony has in part contributed to prosecutors' failure to address police perjury and misconduct. This failure to address police falsification allows fact finder presumptions of officer truthfulness to persist despite the prevalence of police perjury. These presumptions severely hamper a prosecutor's ability to rebut claims of self-defense raised by police defendants - particularly in cases involving the killing of citizens of color, where cultural narratives of criminality compound the problem. The resulting acquittals and failed indictments perpetuate the culture of impunity for police misconduct and mistreatment of citizens, making such incidents more likely to keep recurring. ${ }^{18}$

17. For the purposes of this Article, the dominant framework of the American criminal system is defined as retributive as this Article focuses on prosecutorial decision-making. Retributivism is the dominant framework within which most prosecutors exercise their discretion. By and large, American prosecutors are guided in their decision-making processes by the three questions that Howard Zehr uses to define a retributive system: "What laws have been broken? Who did it? What do they deserve?" See Howard Zehr, The Little Book of Restorative Justice 20 (2015); See also Alexandra Natapoff, Misdemeanors, 11 AnN. REV. L. \& Soc. ScI. 255, 257 (2015) (noting that the "classic asserted purpose" of the criminal system is to identify wrongdoers). It is worth noting that Natapoff, among other scholars, argues that, although retribution is the "asserted" purpose of the criminal system, in fact the criminal system in the United States primarily functions as a form of social management and control. See id. This is also the argument made by Michelle Alexander in The New Jim Crow, the history of which is outlined by Bryan Stevenson in his essay, A Presumption of Guilt. See Bryan Stevenson, A Presumption of Guilt, in Policing the Black Man: ArRest, Prosecution, and Imprisonment 5 (Angela J. Davis ed., 2017). This Article does not dispute that characterization, nor that it may, in fact, be the dominant framework of the criminal system. However, this Article is focused primarily on individual prosecutors and their decision-making, which is typically oriented around the retributive questions of determining who is responsible for a specific criminal act and what their punishment should be.

18. See, e.g., Patryk Labuda, Racial Reconciliation in Mississippi: An Evaluation of the Proposal to Establish a Mississippi Truth and Reconciliation Commission, 27 Harv. J. Racial \& Ethnic Just. 1, 16 (2011) (arguing that failed 
Lastly, Part III proposes that rather than relying on extrajudicial restorative practices, such as truth commissions, to make up for failures of the retributive system, reformers instead should advocate to integrate more restorative practices into the current criminal system in order to reduce the reliance of prosecutors on police narratives. ${ }^{19}$ Using restorative rather than retributive principles to guide prosecutor decision-making - even while remaining in a largely retributive framework - would necessarily decrease reliance on police testimony because a restorative framework causes prosecutors to focus more on offenses involving victims and less on public order crimes that rely exclusively on officer testimony. ${ }^{20}$ This could create more opportunities to expose and address police misconduct and potentially create a greater acceptance of the narratives of people of color, which currently are often rejected in favor of pro-police narratives. The Article concludes by looking at a few ways to bring about this cultural shift in prosecution, including changes in how law schools and district attorney offices educate and train future prosecutors.

\section{COMBINING INFORMAL AND FORMAL JUSTICE MECHANISMS MAY ACHIEVE BETTER OUTCOMES FOR VICTIMS, OFFENDERS, AND SOCIETY}

Research has shown that when informal justice mechanisms ${ }^{21}$ are used in lieu of formal justice practices, the informal mechanisms have an overall negative impact on democracy and human rights. ${ }^{22}$ Formal

prosecutions "harbor the danger of defeating truth and justice in one fell swoop, making a mockery of the criminal justice system and leaving the victims in an even worse position. Given the long history of illegitimate trials and tacit support of racism ... in the United States, the possibility of defendants walking free with the state's (or federal government's) seal of approval is particularly troubling.")

19. Howard Zehr defines restorative justice as "a process to involve, to the extent possible, those who have a stake in a specific offense or harm to collectively identify and address harms, needs and obligations in order to heal and put things as right as possible." See ZEHR, supra note 17, at 40.

20. See id. at 20 (defining the restorative system by a series of questions: "Who has been hurt? What are their needs? Whose obligations are these?").

21. This Article uses "informal justice" to refer to processes such as truth commissions or other mechanisms that fall outside of traditional, formal criminal adjudications. See Chanbonpin, supra note 16, at 1090 (citing ANDREW WOOLFORD \& R.S. Ratner, Informal Reckonings: Conflict Resolution in Mediation, RESTORATIVE JUSTICE AND REPARATIONS 4 (2008)).

22. See Tricia D. Olsen et al., Transitional Justice in Balance: Comparing Processes, Weighing EFFicACy 144 (2011). In particular, the study showed that truth commissions, working alone, had an overall negative impact on 
justice practices, such as criminal prosecutions, seek to uphold human rights norms and values through accountability, proportional retribution, and procedural fairness. ${ }^{23}$ Allowing wrongdoingparticularly state-sanctioned wrongdoing - to go unpunished risks undermining human rights. ${ }^{24}$ Combining formal and informal justice systems has been shown to have a positive impact on human rights. ${ }^{25}$ This Part explores a few of the shortcomings of both the formal and informal justice systems ${ }^{26}$ including one of the most commonly used informal justice mechanisms - the truth commission. ${ }^{27}$ It then explores some of the ways that combining restorative and retributive approaches could overcome some of these shortcomings.

\section{A. Perpetrator Denial May Thwart Informal Justice Practices}

Informal justice practices, including truth commissions and other restorative processes, tend to succeed only when perpetrators

transitional justice. See id. The author, however, did find that a combination of truth commissions, amnesties, and trials had a positive impact on democracy and human rights, confirming the "holistic approach" to transitional justice. See id. at 144-46.

23. Richard A. Wilson, The Politics of Truth and Reconciliation in South Africa: Legitimizing the Post-Apartheid State (2001).

24. See id. at 230. (" $[\mathrm{I}] \mathrm{t}$ is misguided to delegitimize human rights at the national level by detaching them from a retributive understanding of justice and attaching them to a religious notion of reconciliation-forgiveness, a regrettable amnesty law and an elite project of nation-building. Democratizing regimes should not seek legitimacy through nation-building, efforts to forge a moral unity and communitarian discourses, but on the basis of accountability and justice defined as proportional retribution and procedural fairness. The role of human rights and the rule of law in all of this is to create the bedrock of accountability upon which democratic legitimacy is built.").

25. See Tricia D. Olsen et al., The Justice Balance: When Transitional Justice Improves Human Rights and Democracy, 32 HuM. RTS. Q. 980, 982 (2010) (citing an empirical analysis indicating that both trials and amnesty were a necessary, but not sufficient, component of transitional justice, and that combined approaches of either trials and amnesty or trials, amnesty and truth commissions were the only circumstances which saw significant positive results); see also Miriam Aukerman, Extraordinary Evil, Ordinary Crime: A Framework for Understanding Transitional Justice, 15 HARV. HuM. RTS. J. 39, 43 (2002).

26. Note that this Article attempts to address shortcomings of these systems only in principle, not in practice. Addressing the countless injustices of the American criminal system in practice is far beyond the scope of this Article.

27. See Olsen, supra note 25 , at 982 (defining truth commissions as "an alternative, victim-oriented restorative justice mechanism that holds perpetrators accountable through non-judicial processes."). Other non-judicial accountability schemata include reports by international delegations, lustration, civil liability, reparations, and historical inquiry. See Aukerman, supra note 25, at 43. 
take responsibility for their actions. ${ }^{28}$ Criminal justice scholars note that "an important antecedent to rehabilitation" is for offenders to accept responsibility for their wrongdoing. ${ }^{29}$ For victims, acts of violence send the message that their lives are of less value than that of the perpetrator. ${ }^{30}$ The acknowledgement of wrongdoing through the acceptance of responsibility and the showing of true remorse counters this message and may serve to undo some of the harm wrought. ${ }^{31}$ Thus, acceptance of blame is a critical component for both the victim and the perpetrator to move forward.

Unfortunately, informal justice does not offer a clear means to ensure victim healing when perpetrators deny wrongdoing. ${ }^{32}$ Admitting wrongdoing, particularly where one's actions are

28. See ZEHR, supra note 17, at 46 ("[T] here is a prerequisite that the offender acknowledge, at least to some extent, his or her responsibility."); see also Oliver Diggelmann, International Criminal Tribunals and Reconciliation: Reflections on the Role of Remorse and Apology, 14 J. INT'L CRIM. JUST. 1073, 1086 (2016) (“Empirical research has found that victims of human rights abuses are indeed more forgiving when they believe a wrongdoer is truly sorry.").

29. See James W. Diehm, Pleading Guilty While Claiming Innocence: Reconsidering the Mysterious Alford Plea, 26 U. FlA. J.L. \& PuB. Pol'y 27, 39 (2015); see also Stephanos Bibas, Harmonizing Substantive Criminal Law Values and Criminal Procedure: The Case of Alford and Nolo Contendere Pleas, 88 CORNELL L. REV. 1361, 1363 (2003) (arguing that pleas that allow offenders to forego accepting responsibility for their offense impede the reform, education, and condemnation of guilty defendants).

30. Jean Hampton, The Retributive Idea, in ForgIVENESS AND MERCY (1998) ("[T]he retributive motive for inflicting suffering is to annul or counter the appearance of the wrongdoer's superiority and thus affirm the victim's real value.").

31. See Diggelmann, supra note 28, at 1079 ("Sincere remorse . . can have an amazing healing effect. Particularly face-to-face expressions of remorse may matter immensely to victims. Research has shown that a substantial percentage of victims are highly interested in meeting with offenders. Seeing the offender himself suffer may open up a road to reconnect. Remorse is painful, and as suffering from pain cannot be evil, there is always some 'good' in meetings between remorseful offenders and victims. The victim 'visits' the wounds of the perpetrator. Symbolically, the moral balance is restored, at least partially. The message of the crime - that the community norms do not apply to the wrongdoer and that he is superior to the victim - is modified."). See, e.g., Lindsey Bever, A Rape Victim was Just Awarded \$1 Billion. Jurors Told Her: 'You're Worth Something.', WASH. Post (May 24, 2018), https://www.washingtonpost.com/news/post-nation/wp/2018/05/24/

a-rape-victim-was-just-awarded-1-billion-jurors-told-her-youre-worthsomething/?noredirect=on\&utm_term=.6c286b9e7331 [https://perma.cc/3D59XPWC]. But see Rocksheng Zhong, So You're Sorry? The Role of Remorse in Criminal Law 11 (2013) (unpublished M.D. thesis, Yale University) (arguing that there is actually no clear empirical evidence to support a correlation between remorse and decreased recidivism).

32. See ZEHR, supra note 17, at 46. 
reprehensible or shameful, is incredibly difficult. ${ }^{33}$ Perpetrators may avoid these feelings of shame by lying not only to others - their family, friends, and the public — but also to themselves. ${ }^{34}$ In this state of denial, the perpetrator loses the opportunity to acknowledge his or her wrongdoing, examine its underlying causes, and ultimately change his or her behavior. ${ }^{35}$ Without an external mechanism to challenge that denial, he or she is permitted to persist in believing that he or she is without blame. ${ }^{36}$ As an informal process, restorative practices lack the institutional authority to counteract this denial. ${ }^{37}$ Failure to dispel denial increases the risk of recidivism for the individual, ${ }^{38}$ and failure to meaningfully condemn the perpetrator's actions increases the risk of more of the same behavior in society as a whole. ${ }^{39}$ When society fails to condemn wrongdoing, it fails to enforce societal norms and the collective moral code, contributing to their degradation. ${ }^{40}$ Perhaps for these reasons, victims of human rights abuse tend to indicate higher levels of satisfaction in prosecution than in informal practices such as truth commissions, ${ }^{41}$ and they often see prosecutions as more likely to achieve communal goals of truth and justice. ${ }^{42}$

33. See Bibas, supra note 29, at 1393.

34. See id.

35. See id. at 1395. Howard Zehr argues that "those who have caused harm need justice to provide[] accountability that addresses the resulting harms, encourages empathy and responsibility, and transforms shame." ZEHR, supra note 17, at 25.

36. See Bibas, supra note 29, at 1390-91 (arguing that inadequate response to offender denial of wrongdoing leaves in place the psychological denial mechanisms of offenders).

37. See ZEHR, supra note 17 , at 76 (recognizing that it is the strength of the retributive system, not the restorative system, to identify the origin of harm and wrongdoing). For truth commissions in particular, this inability may be due to any number of factors - the inability of a commission to offer amnesty for admission of wrongdoing, unofficial commissions lacking subpoena power or the ability to grant immunity, or simply the lack of incentive due to a lack of threat of punishment.

38. Bibas, supra note 29, at 1390-91 ("Punishment seeks to teach by triggering and developing the offender's sense of guilt. It tries to induce contrition and repentance so that the offender will repudiate his past wrongful act and avoid committing it again.").

39. Richard A. Wilson, Challenging Restorative Justice, 2 Hum. RTS. DiAlogue 7 (2002), ("The delegitimation of human rights in relation to popular understandings of justice is also one factor in the upsurge of criminality in South Africa. At the high point of resistance to apartheid in 1986, there were 9,913 homicides in South Africa; in the year 2000, there were 23,823.”).

40. Id. See Bibas, supra note 29, at 1390-91.

41. See Matiangai V.S. Sirleaf, Beyond Truth and Punishment in Transitional Justice, 54 VA. J. INT'L L. 223, 275-76 (2014).

42. See Raquel Aldana-Pinedell, An Emerging Universality of Justiciable Victims' Rights in the Criminal Process to Curtail Impunity for State-Sponsored 


\section{B. The Formal Justice System is Uniquely Equipped to Overcome Denial of Wrongdoing}

It is largely within the province of prosecutors to condemn wrongdoing and uphold society's moral code through the initiation of criminal charges. ${ }^{43}$ Prosecutors choose whose behavior warrants criminal charges and whose does not, ${ }^{44}$ and prosecutors choose which charges to bring and which to forego. ${ }^{45}$ In so doing, they send a message to the larger community about what types of behavior are and are not acceptable in our society. Through the adversarial process, prosecutors use the threat of sanction to confront and overcome perpetrator denial of wrongdoing. ${ }^{46}$ It is here that restorative justice scholars acknowledge that the retributive system finds its greatest strength: enforcing human rights by using the adversarial process to identify the true origin of harm, even where perpetrators deny culpability. ${ }^{47}$

Because prosecutors have typically declined to pursue charges, most police shootings have not been subject to the adversarial process. ${ }^{48}$ Of the few that have, even fewer have resulted in convictions. ${ }^{49}$ Thus there are few cases of police shootings of civilians

Crimes, 26 Hum. RTs. Q. 605, 607 (2004) (noting that many survivors of human rights abuses believe that only the effective prosecution of human rights violators will yield their goals of truth and justice and prevent future victimization).

43. See Criminal Justice Standards for the Prosecution Function § 31.2 (AM. BAR ASS'N 2015).

44. See id.

45. See id.

46. Bibas supra note 29, at 1397 ("Even external pressures, such as the threat of imprisonment, can induce offenders to overcome their denial.").

47. See ZEHR, supra note 17 , at 76 .

48. The Washington Post and researchers at Bowling Green State University have analyzed fatal police shootings since 2005 . Their analysis revealed that the overwhelming majority of incidents resulting in criminal charges involved both an unarmed victim as well as other factors that made the case exceptional, including "a victim shot in the back, a video recording of the incident, incriminating testimony from other officers or allegations of a cover-up." This phenomenon led one researcher to note, "to charge an officer in a fatal shooting it takes something so egregious, so over the top that it cannot be explained in any rational way." Levine, supra note 10, at 764 (quoting Kindy \& Kelly, supra note 15).

49. See Davis, supra note 15, at xi; Madison Park, Police Shootings: Trials, Convictions Are Rare for Officers, CNN (October 3, 2018) https://www.cnn.com/

2017/05/18/us/police-involved-shooting-cases/index.html [http://perma.cc/JZS2X5DG] ("Few police officers ever face trial for shooting deaths, let alone are convicted.") Two recent counter-examples: The killing of Laquan McDonald which, after a protracted legal battle to release the video footage of the incident, went to trial 
to rely upon to illustrate this principle of the way in which exposure to the adversarial process can overcome perpetrator denial. However, the case of Michael Slager is informative, particularly for cases involving white officers shooting unarmed men of color. Michael Slager was a white South Carolina police officer charged with shooting and killing Walter Scott, a black man, during a traffic stop. ${ }^{50}$ Initially Slager claimed self-defense, stating that he feared for his life because Scott took his stun gun while attempting to flee. ${ }^{51}$ Video of the incident contradicted these claims, showing Slager shooting Scott eight times in the back and then appearing to plant an objectpresumably the stun gun-next to his body. ${ }^{52}$

At trial, Slager persisted in his denial of wrongdoing. He testified that he acted in self-defense and was in "total fear" during his interaction with Scott. The jury was unable to reach a verdict, but indicated to the attorneys that they were within one vote of convicting Slager of manslaughter. ${ }^{53}$ After the jury hung, the victim's mother, Judy Scott, was interviewed by reporters and expressed her hope for a future conviction, stating, "Injustice will not prevail." 54 With the information from the jury indicating that a second trial could very well result in a guilty verdict, Slager pleaded guilty to the federal civil

and resulted in a guilty verdict on the charge of second-degree murder. The officer convicted in that matter, Jason Van Dyke, is the first Chicago officer to be charged with murder for an on-duty shooting in roughly fifty years. Don Babwin \& Michael Tarm, Officer Convicted of Murder in Slaying of Laquan McDonald, AP NEws (Oct. 5, 2018), https://apnews.com/862ebaf6890d44de80c0ae74cac3949e [http://perma.cc/8GUX-AMTX]. In addition, in August of 2018, a Texas jury found former police officer Roy Oliver guilty of murder for the killing of an AfricanAmerican high school freshman Jordan Edwards. Oliver had fired into a car full of teenagers, including fifteen-year-old Jordan, and was sentenced to fifteen years. Faith Karimi \& Emanuella Grinberg, Texas Ex-Officer Is Sentenced to 15 Years for Killing an Unarmed Teen, CNN (Aug. 30, 2018), https://www.cnn.com/2018/08/29/

us/texas-jordan-edwards-death-sentencing-phase/index.html [https://perma.cc/8293$3 \mathrm{XJY}]$. ("[T] he rare guilty verdict in the trial of a police officer prompted gasps and sobs in the courtroom ... Most police-involved shootings deaths . . . have ended in acquittals or no charges.")

50. See Alan Blinder, Michael Slager, Officer in Walter Scott Shooting, Gets 20-Year Sentence, N.Y. TIMES (Dec. 7, 2017), https://www.nytimes.com/

2017/12/07/us/michael-slager-sentence-walter-scott.html?_r $=0$

[https://perma.cc/GAH8-LGER].

51. See id.

52. See id.

53. See Alan Blinder, Mistrial for South Carolina Officer Who Shot Walter Scott, N.Y. TIMES (Dec. 5, 2016), https://www.nytimes.com/2016/12/05/us/walterscott-michael-slager-north-charleston.html [https://perma.cc/5GGZ-CRTC].

54. Id. 
rights violations in exchange for the state charges being dropped. ${ }^{55} \mathrm{At}$ his sentencing hearing, Slager told the court "Walter Scott is no longer with his family, and I'm responsible for that. I wish it never would have happened. I wish I could go back in time." ${ }^{56}$ In response, Mrs. Scott forgave him. He then silently mouthed to her the words, "I'm sorry," and she replied, "I know." 57 Slager was then sentenced to twenty years in prison. ${ }^{58}$

After the hearing, Mrs. Scott told reporters, "I'm supposed to be really angry and upset and raging but I can't — because of the love of God in me, I can't be like that. I feel forgiveness in my heart, even for the guy that shot and killed my son." ${ }^{59}$ Based on her earlier statement about justice, at least some of her forgiveness seems to have been predicated on Slager having been held accountable. ${ }^{60}$ The "external pressures" of the system - in this case the combined actions of state

55. See Michael Sokolove, What Does It Take to Convict a Cop?, MotHeR JONES (2017), https://www.motherjones.com/politics/2017/05/michael-slager-trialwalter-scott-police-shooting-north-charleston-south-carolina-3/

[https://perma.cc/Y375-K3FJ].

56. Blinder, supra note 50. This expression is similar to one made by Eugene de Kock at the South African Truth and Reconciliation Commission to two women whose husbands he had murdered. As recounted by Pumla Gobodo-Madikizela, de Kock tells the women, with tears in his eyes, "I wish there was a way of bringing their bodies back alive. I wish I could say, here are your husbands . . . . But unfortunately, ... I have to live with it." Gobodo-Madikizela marks this as a moment in which she and the women experienced empathy for de Kock because his expression of empathy and remorse appeared genuine. Jodi Halpern \& Harvey M. Weinstein, Rehumanizing the Other: Empathy and Reconciliation, 25 HuM. RTS. Q. 561, 573 (2004) (citing Pumla Gobodo-Madikizela, Remorse, Forgiveness, and Rehumanization: Stories from South Africa, 42 J. Humanistic PsychOl. 7 (2002)). It is notable that while de Kock received amnesty for crimes he committed for political reasons, he was not pardoned on eighty-nine of the charges against him and was ultimately sentenced to 212 years in prison. He was one of only three white men after 1994 jailed for apartheid atrocities. Antjie Krog, Can an Evil Man Change?, N.Y. Times (Mar. 13, 2015), https://www.nytimes.com/2015/03/14/opinion/sunday/

the-repentance-of-eugene-de-kock-apartheid-assassin.html [https://perma.cc/D4PX7PZ4].

57. See Blinder, supra note 50. The silent "I'm sorry" appeared to be for the benefit of Walter Scott's mother, not the court. Lindsey Bever, 'Forgiveness Is in My Heart,' A Bereaved Mother Told the Officer Who Shot Her Son in the Back, WASH. Post (Dec. 7, 2017), https://www.washingtonpost.com/news/inspiredlife/wp/2017/12/07/forgiveness-is-in-my-heart-a-bereaved-mother-told-the-officerwho-shot-her-son-in-the-back/?utm_term=.3cb124c368aa [https://perma.cc/P4L5N48Y] ("I forgive Michael Slager. I forgive you. Forgiveness is in my heart.")

58. Blinder, supra note 50.

59. See Bever, supra note 57.

60. See Bever, supra note 57 (quoting Judy Scott from 2015, prior to the trial, “He's got to get convicted."). See also Diggelmann, supra note 28, at 1079. 
and federal prosecutors pursuing charges - forced Slager to confront and eventually overcome his denial. ${ }^{61}$ Slager was able to make some amends and the victim's family acknowledged some degree of restoration, leading to what appeared to be a genuine "re-balancing of the scales." ${ }^{62}$ The prosecutors' use of the criminal system in this case condemned the unjustified killing of an unarmed civilian of color by a police officer. By pursuing the charges, prosecutors rejected Slager's self-defense claim, which ultimately pushed Slager to surrender his denial and accept responsibility for the life he had taken.

\section{The Formal Justice System Oversimplifies Both Harms and Parties, Making It Incapable of Meaningfully Addressing Systemic Injustice}

While the retributive system has a unique strength in overcoming denial, this is partially because its adversarial nature focuses almost exclusively on the question of guilt. ${ }^{63}$ This can marginalize and silence victim experiences. In the criminal system, the opportunities for victim-offender confrontation are limited both in time and in scope and are always subject to the adversarial nature of the proceeding. This can mean that victims seeking to be heard are curtailed by time constraints, cross-examination, or relevancy objections, limiting their opportunity for restoration. The focus on proving guilt has caused many victims to feel "disillusioned with the adversarial system . . . and pin their hopes on non-adversarial restorative justice mechanisms, such as truth-telling." ${ }^{64}$ The retributive schema takes what is often a complex web of stories and artificially reduces the number of participants and narratives in order to exclusively answer the question of who is most directly at fault.$^{65}$ Very few acts of violence affect only the individuals directly involved; family members, friends, community members, witnesses, and others may be directly or indirectly affected. ${ }^{66}$ Excluding the wider community can leave survivors shouldering their trauma alone,

61. Bibas, supra note 29, at 1363-1365 (describing the case of Kathleen Soliah, who only accepted responsibility and apologized for her role in the kidnapping of Patricia Hearst after a judge denied her attempt to withdraw her guilty plea).

62. See ZEHR, supra note 17 , at 59 (arguing that both retribution and restoration share a primary goal of "balancing the scales" when a harm has been caused or a wrong done).

63. See Labuda, supra note 18 , at 30.

64. See id.

65. See id.

66. See id. at 17. 
without a sense of their place in a larger story of injustice and communal trauma. In addition, the singular focus on individual perpetrators tends to "absolve other [parties, including] states, groups, bystanders[,] and the rest of society of any responsibility." ${ }^{67}$ Thus, the retributive system's sole focus on proving individualized guilt inhibits opportunities to probe society's complicity in systemic problems like racially motivated violence. ${ }^{68}$

Because the retributive system focuses almost exclusively on the question of individual guilt, it also artificially reduces the scope of the offense, limiting its ability to seat the incident in the context of a particular community, power dynamic, or historical legacy. ${ }^{69}$ "[A]lthough litigation is adept at resolving claims based on discrete events and individual experiences, it is not conducive to the recognition of collective, inter-generational injuries wrought by structural and systemic causes." ${ }^{\circ 0}$ Criminal trials do not typically give voice to a full airing of the societal circumstances, factors, and values that shape and inform the individual actions of the participants. This is particularly true for historical or systemic factors that are, from a court's perspective, too attenuated to be relevant to the question of guilt and thus inadmissible at trial.

The criminal system alone, then, is unlikely to effectively change police practices or present a meaningful challenge to historical legacies, such as the systemic racism pervading police departments

67. See Sirleaf, supra note 41 , at 249 . A recent example would be the Larry Nassar case, which, had it gone to trial, likely would have focused exclusively on Nassar's conduct, potentially obscuring the roles of the countless individuals who facilitated and covered up the abuse. See, e.g., Eric Levenson, Larry Nassar Sentenced to up to 175 Years in Prison for Decades of Sexual Abuse, CNN (Jan. 24, 2018), https://www.cnn.com/2018/01/24/us/larry-nassar-sentencing/index.html

[https://perma.cc/H24L-QJD2]; see also Lauren Green, U.S. Gymnast Maggie Nichols Says She Was Abused by Larry Nassar, Dissuaded From Coming Forward By USA Gymnastics, SPORTS ILLUSTRATED (Jan. 9, 2018), https://www.si.com/olympics/ 2018/01/09/maggie-nichols-larry-nassar-sexual-abuse-usa-gymnastics

[https://perma.cc/JDP7-5YB4]; Matt Pearce, Michigan State University President Resigns Amid Widening Calls for Accountability over Larry Nassar Abuse Scandal, L.A. Times (Jan. 24, 2018), http://www.latimes.com/nation/

la-na-nassar-accountability-20180124-story.html [https://perma.cc/S8PA-RN47].

68. See Labuda, supra note 18.

69. See id. at 14 (describing how the individual trials of Klansmen for racially-motivated violence was necessary, but not sufficient, as they focused "on a narrowly circumscribed set of facts [which] meant that much of Mississippi's history remained in the shadows").

70. See Chanbonpin, supra note 16, at 1112 . 
and the criminal justice system. ${ }^{71}$ In cases of police shootings involving civilians of color, two responses tend to emerge to defend officers. One is a full-throated denial that often involves victimblaming and either implicit or explicit allusions to black criminality. ${ }^{72}$ The second is what has been referred to as the "bad apple" narrative, which asserts that credible incidents of unjustified police violence toward citizens of color are aberrations attributable solely to the individual officer. ${ }^{73}$ The former can be addressed through the criminal trial; the latter typically cannot. This individualistic approach to wrongdoing ignores the long legacy of police violence toward Americans of color and the culture of impunity that enables that violence. ${ }^{74}$ This limits the ability to expose and confront systemic racism in policing or to bring about meaningful institutional change. ${ }^{75}$ Viewing these cases individually as anomalies or outliers rather than as part of an ongoing system or practice allows widespread patterns of institutional misconduct to persist. ${ }^{76}$

In contrast to the formal criminal system, an informal justice practice is well positioned to confront "the systemic and historical causes of widespread social harms." ${ }^{\prime 77}$ This process may help society to uncover dynamics of oppression that otherwise would go unrecognized. "Historical inquiry can . . . lay bare the kind of ideologies that gave rise to the crimes being investigated, and in so doing, make us alert to any renewed currents of similar ideologies that

71. See generally Michelle Alexander, The New Jim Crow (2012); Alexandra Natapoff, Punishment Without Crime 149-170 (2018). And see Stevenson, supra note 17, at 26 ("What threatened to kill me on the streets of Atlanta when I was a young attorney wasn't just a misguided police officer with a gun, it was the force of America's history of racial injustice and the presumption of guilt it created.").

72. See generally Paul Butler, Chokehold: Policing Black Men (2017).

73. See Chanbonpin, supra note 16, at 1115 (calling this the "dominant narrative of police torture," which ignores the contributing factors of broader-scale forces such as racism and inadequate police accountability mechanisms); see generally ALEXANDER, supra note 71 (arguing that this notion is reinforced by the Supreme Court's jurisprudence on race and crime that racial animus, whether from a police officer, prosecutor, or party, must be overt and intentional to be recognized and reparable).

74. See Chanbonpin, supra note 16, at 1115 (arguing that the bad apple narrative "renders invisible the State's complicity in police torture").

75. See id. at 1108.

76. See id.

77. See id. at 1108. 
could, if we are not watchful, lead to similar crimes." 78 Truth commissions in particular can also help divided societies arrive at a universally accepted truth through exhaustive historical accounting combined with the testimony of affected individuals. ${ }^{79}$ Through that process, truth commissions allow space for more than one kind of truth. ${ }^{80}$

While the criminal system necessarily values some narratives more than others in order to ascertain guilt, truth-telling spaces may give victims the opportunity to gather and take part in creating a narrative outside of the "official story" of the incident. ${ }^{81}$ The more expansive scope of inquiry and "more informal and inclusive approach to testimony" allow informal justice mechanisms to forgo weighing truths and instead allow more narratives to enter the public sphere. ${ }^{82}$ This can begin to help societies dismantle pervasive stereotypes and narratives. "[I]t has been argued that the way to make a deep cultural transformation is through the dissemination of counter-narratives, narratives that undermine or counterbalance the dominant masterplots of a culture and thus weaken the power of prejudicial types." ${ }_{83}$

Truth commissions and other informal justice mechanisms, by permitting statements and narratives that may be disfavored in adversarial criminal trials, create a space for that dissemination. In the case of police shootings of Americans of color, stereotypes and dominant cultural narratives play a tremendous role both in the way

78. Teresa Goodwin Phelps, Shattered Voices: Language, Violence, AND THE WORK OF TRUTH COMMISSIONS 80 (2006).

79. James L. Gibson, Overcoming Apartheid: Can Truth Reconcile a Divided Nation?, 603 Annals Am. ACAD. Pol. \& Soc. SCI. 82, 93 (2006) ("One of the objectives of the truth and reconciliation process was to create a collective memory for South Africa. A collective memory is an accepted version of the truth about the country's past. By establishing a collective memory, it becomes difficult (although not impossible) for people to deny that certain activities took place.").

80. See Truth AND Reconciliation Commission, Truth AND ReConciliation COMmission OF SOUth Africa Report 110 (1998) (discussing the work of the Commission that led to "four notions of truth: factual or forensic truth; personal or narrative truth; social or 'dialogue' truth . . . and healing and restorative truth."); see also Chanbonpin, supra note 16, at 1115-16 (criticizing the four-part credibility test utilized by the Chicago Torture Commission as replicating the problems of the retributive system — including the "bad apple" narrative- by failing to allow for multiple forms of truth).

81. See Lisa Magarrell \& Joya Wesley, Learning from Greensboro: TRUTH AND RECONCILIATION IN THE UNITED STATES 39 (2008).

82. Id.

83. H. Porter Abbott, The Cambridge Introduction to Narrative 188 (2d ed. 2008). 
the cases are treated by the criminal system and the way they are perceived by the public. ${ }^{84}$ Prosecutors can take the first step in rejecting these narratives by bringing criminal charges against officers whose self-defense claims invoke them, like the prosecutors did in the Michael Slager case and in the prosecution of Jason Van Dyke, the officer who shot and killed Laquan McDonald in Chicago. ${ }^{85}$ Communities can take the second step after the prosecution is concluded by engaging in truth and reconciliation practices that further expose and confront those stereotypes in order to help all community members move past them.

D. Neither a Formal Retributive Justice System nor Informal Restorative Justice Practices Are Sufficient to Bring About Reconciliation

Restorative justice practices offer a less adversarial space in which deeper reconciliation between the parties can take place after the work of determining fault is over. Their focus on restoring victims to wholeness can balance the formal justice system's singular focus on perpetrators. Restorative practices that bring in the larger community can create a space for more stakeholders to be heard or to bear witness. The retributive system can help lay the groundwork for reconciliation in these spaces by challenging cultures of impunity through accountability, providing mechanisms whereby perpetrators are incentivized to accept responsibility for their wrongdoings, and allowing all parties to enter the informal justice space on even ground without replicating dynamics of oppression. Informal justice practices, including truth-telling, restorative circles, and victim-offender mediation, can create a space for the unofficial stories of victims to be heard and disseminate these unofficial stories into society. This could expand society's understanding of cultural narratives and ultimately help dispel harmful stereotypes.

84. See infra Part II (exploring the ways in which deep-seated cultural stereotypes about black criminality affect case outcomes for African Americans both as defendants and victims).

85. See Babwin \& Tarm, supra note 49. See also Greg Allen, 'Today We Have Justice'-Florida Police Officer Convicted in 2015 Shooting, NPR, https://www.npr.org/2019/03/07/701266147/today-we-have-justice-florida-policeofficer-convicted-in-2015-shooting [https://perma.cc/2ETT-2A3P] (describing the guilty verdict in the shooting death of Corey Jones despite the self-defense claim raised by former Palm Beach Gardens police officer Nouman Raja). 
However, the benefits of the formal justice system are lost when prosecutors fail to first obtain justice for victims. ${ }^{86}$ Without the condemnation associated with criminal charges and-perhaps more importantly - convictions, the denial of wrongdoing or the belief that one's actions are condoned by society persists and may further enable individual and systemic violence. This is already a concern for police officers who are given tremendous authority, discretion, and power in how they interact with citizens. It is of particular concern in cases involving police interactions with citizens of color. Despite the need for criminal prosecution of officer misconduct to uphold society's moral code and despite the unique position of the formal justice system to overcome officer denial of misconduct, prosecutors rarely exercise their ability to charge officers. The next Part addresses one set of factors among many for this failure of American prosecutors to successfully pursue charges against police officers.

\section{PROSECUTOR DEPENDENCY ON POLICE WITNESSES BREEDS COMPLICITY WITH POLICE MISCONDUCT}

The case of Michael Slager is a true outlier. Throughout the criminal system, injustice routinely prevails. ${ }^{87}$ Numerous factors contribute to the sense of a double standard for officer behavior: (1) the law's permissiveness toward the use of deadly force by police, ${ }^{88}$

86. Aldana-Pinedell, supra note 42, at 607 ("Impunity, therefore, arises when states fail to investigate, prosecute and punish right to life and humane treatment violations in accordance with their duty to prosecute. Impunity also generally refers to states' widespread failure to carry out their duty to prosecute, although impunity can also exist in individual cases or as to specific types of offenses or victims within a criminal justice system.”).

87. See Capers, supra note 6, at 847 (referring to the initial acquittal of the officers who attacked Rodney King as the rule, not the exception, evidencing that in the rare case where the government does bring an indictment, convictions are even rarer still); see also Blinder, supra note 50 ("The case against Mr. Slager is one of the few instances in which a police officer has been prosecuted for an on-duty shooting."). Recently, an officer was acquitted in Allegheny County, Pennsylvania for shooting and killing Antwon Rose, an unarmed black teenager in the back while the teen fled during a traffic stop. The defendant had been an East Pittsburgh police officer for three weeks, and previously left the University of Pittsburgh police force "after discrepancies were found between one of his sworn statements and evidence in an arrest." Adeel Hassan, Antwon Rose Shooting: White Police Officer Acquitted in Death of Black Teenager, N. Y. TIMES (Mar. 22, 2019), https://www.nytimes.com/2019/03/22/us/antwon-rose-shooting.html [https://perma.cc/RD47-UBKZ].

88. Deadly Force: Police Use of Lethal Force in the United States, AMNESTY INT'L (June 17, 2015), https://www.amnestyusa.org/reports/deadly-force-police-use- 
(2) the police code of silence - often referred to as "the blue wall of silence," $"$ (3) the differential treatment of police defendants in the criminal system - particularly the indicting grand jury system, ${ }^{90}(4)$ the heightened presumption of innocence and burden of proof in cases involving officer defendants, and-in the case of victims of color(5) persistent tropes and stereotypes about the lawlessness of non-

of-lethal-force-in-the-united-states/ [https://perma.cc/726X-GVED] ("Amnesty International reviewed US state laws - where they exist - governing the use of lethal force by law enforcement officials and found that they all fail to comply with international law and standards. Many of them do not even meet the less stringent standard set by US constitutional law."). Amnesty International found that all fifty states and Washington, D.C. fail to comply with international law and standards on the use of lethal force by law enforcement officers. Id. Nine states and Washington, D.C. currently have no laws on use of lethal force by law enforcement officers. Id. Thirteen states have laws that do not comply with the lower standards set by United States constitutional law on use of lethal force by law enforcement officers. Id. No state requires that the use of lethal force be used only as a last resort and for less harmful means to be tried first. $I d$. No state limits the use of lethal force to only those situations where there is an imminent threat to life or serious injury to the officer or to others. $I d$.

89. The "blue wall of silence" is typically defined as the way in which police either refuse to testify against one another or testify favorably, albeit untruthfully, to protect one another from criminal allegations. See Levine, supra note 10, at 749; see also Milton Mollen et. al, Comm'n to Investigate Allegations of Police Corruption and the Anti-Corruption Procedures of the Police Dep't, Anatomy of Failure: A PATH For Success 53 (1994) [hereinafter Mollen COMmission Report]; Gabriel J. Chin \& Scott C. Wells, The "Blue Wall of Silence" as Evidence of Bias and Motive to Lie: A New Approach to Police Perjury, 59 PITT. L. REV. 233, 237 (1998).

90. See Ric Simmons, The Role of the Prosecutor and the Grand Jury in Police Use of Deadly Force Cases: Restoring the Grand Jury to Its Original Purpose, 65 CLEV. ST. L. REV. 519, 522, 524 (2017) (noting that nearly all non-police defendant cases sent to an indicting grand jury result in indictments being returned, yet the majority of cases involving police officers do not); see also Levine, supra note 10, at 755-56 ("[W]hen the police are the suspects, the usual charge and indictment process appears to unravel. This can be seen in the unusually detailed presentation of evidence to the grand jury in the choking death of Eric Garner at the hands of police in Staten Island, New York, which lead to no indictment. It is also apparent in the investigation into the police shooting of twelve-year-old Tamir Rice in Cleveland, Ohio, and the grand jury's decision not to indict there. It took the prosecutor more than a year to present the case to a grand jury, and before doing so, three commissioned independent reports were released discussing the facts of the shooting and concluding that the officers had not committed criminal acts. This seemingly extraordinary process for police suspects, before they formally become defendants through charge or indictment, has been maligned by the public, the legal community, and scholars. It has been seen as a way for prosecutors to exculpate criminal suspects whom they do not want to prosecute."). 
white citizens. ${ }^{91}$ All of these areas, and more, have generated calls for reform..$^{92}$

As argued in Section I.C, criminal charges are a necessaryalbeit not sufficient-step toward ending the culture of impunity surrounding police violence. ${ }^{93}$ Yet, American prosecutors are heavily dependent on police officers to make out their cases, making prosecutors often reluctant to pursue charges against them..$^{94}$ This dependency is heightened in cases involving public-order offenses or other "victimless" crimes where officer testimony is the only evidence offered. If prosecutors used restorative rather than retributive practices to drive decision-making, they would rely less on police testimony overall, decreasing dependency. This Article will address that

91. See Robert M. Entman \& Kimberly A. Gross, Race to Judgment: Stereotyping Media and Criminal Defendants, 71 L. \& ConTEMP. Probs. 93, 97-100 (2008) ("Media stereotypes consist of recurring messages that associate persons of color with traits, behaviors, and values generally considered undesirable, inferior, or dangerous. In the context of crime coverage, there is considerable evidence that media portray blacks and Latinos as criminal and violent.") (citing research indicating that people of color are more likely to appear as lawbreakers, particularly in violent crime features, that depictions of black suspects tend to be more symbolically threatening, and that images of poverty tend to conflate crime, violence and people of color); see also Bryan Adamson, Reconsidering Pre-Indictment Publicity: Racialized Crime News, Grand Juries and Tamir Rice, 8 ALA. C.R. \& C.L. L. REV. 1, 31 (2017); Lee \& Ifill, supra note 7, at 260 ("At the heart of this discrimination is the automatic association between 'blackness' and criminality that is the product of the longstanding dehumanization of black people throughout American history.")

92. See Capers, supra note 6, at 874-75 ("One, where there is reasonable suspicion that an officer has engaged in testilying, investigation should be mandatory and two, where the investigation establishes probable cause to believe that testilying occurred, prosecution should be mandatory. In the federal system, Department of Justice policy already limits the discretion of prosecutors to decline prosecution in certain cases. States have also moved toward limiting prosecutorial discretion, notably in the area of domestic violence. Compulsory prosecution is also a common feature of regulatory agencies and European jurisdictions."); Chin \& Wells, supra note 89, at 289 (proposing jury instructions on the blue wall of silence); Levine, supra note 10, at 755-56 (arguing for the appointment of special prosecutors and changes to the grand jury system). See also Kate Levine, Who Shouldn't Prosecute the Police, 101 IowA L. REV. 1447, 1494 (2016).

93. See infra Section I.C.

94. See Chin \& Wells, supra note 89, at 263 ("Prosecutors may be reluctant to prosecute police officers .... . Most state prosecutors have relatively small investigative staffs; they depend on the police departments to investigate and prove their cases. Accordingly, a prosecutor sensitive to the need to maintain a good working relationship with the police department, and realizing that she cannot succeed in her job without police assistance, might reasonably hesitate to prosecute a police officer for a crime that would put a private citizen behind bars."). 
argument in detail in Part III. ${ }^{95}$ In the rare cases where prosecutors do bring charges, officers are often acquitted due in no small part to credibility assumptions that judges and jurors make in favor of police narratives. This is despite a well-documented problem of police perjury. These narratives often intersect with implicit biases and harmful stereotypes that work against prosecutors when pursuing charges against officers for acts of brutality against citizens of color. As Bennett Capers has argued, police brutality persists in part because officers know they can get away with misrepresenting the truth. ${ }^{96}$ If prosecutors respond more assertively, this sense of impunity will be diminished, and officer misconduct may decrease. ${ }^{97}$

\section{A. Police Perjury Is Common and Prosecutors Are-Knowingly or Unknowingly-Complicit ${ }^{98}$}

Routine police perjury is not a new feature of the American criminal system. In 1967, law professor, practitioner, and judge Irving Younger was lamenting police falsification of evidence as "commonplace." "99 By 1994, the Mollen Commission had concluded that police perjury is "widely tolerated by corrupt and honest officers

95. See infra Part III.

96. See Capers, supra note 6, at 866 ("Police brutality persists, at least in part, because officers are aware that they can misrepresent the truth with impunity. And racial profiling thrives, at least in part, because officers know they can misrepresent their motives for conducting stops without consequences. This suggests that a reduction in testilying might have the collateral effect of contributing to a reduction in brutality and profiling.").

97. See id.

98. The author acknowledges that some police departments may hide or refuse to share evidence of officer misconduct, including evidence suggesting perjury, from prosecutors. $I d$. at 870 . This leaves prosecutors either entirely in the dark or, if suspicious of officer testimony, unable to confirm their suspicions sufficiently to take action beyond declining to call the officer as a witness. See id.; see also Jennifer Gonnerman, Larry Krasner's Campaign to End Mass Incarceration, NEw YORKER (Oct. 29, 2018), https://www.newyorker.com/ magazine/2018/10/29/larry-krasners-campaign-to-end-mass-incarceration [https://perma.cc/Q6HF-5SRW] (noting that even the District Attorney of Philadelphia has been unable to obtain information regarding officer complaints from the Internal Affairs Department).

99. See Irving Younger, The Perjury Routine, NAtion, May 3, 1967, at 59697 ("Every lawyer who practices in the criminal courts knows that police perjury in commonplace"). For further discussion, see also Younger's later opinion as judge in People v. McMurty, 314 N.Y.S.2d 194, 197 (Crim. Ct. 1970) (finding that police perjury exists "beyond any doubt"). 
alike, as well as their supervisors," ${ }^{100}$ and that police falsificationdefined as testimonial perjury, documentary perjury, or the falsification of police records - is one of the most common forms of police corruption. ${ }^{101}$ The practice of police perjury is so common that it spawned its own term: "testilying." 102 Interviews with prosecutors, defense attorneys, and judges reveal that police lies are so pervasive that even former prosecutors have described them as "commonplace" and "prevalent." ${ }^{103}$ Recently, in New York City, journalists uncovered enough cases of probable testilying to conclude that the city has "an entrenched perjury problem." ${ }^{104}$ New York is not alone. ${ }^{105}$

100. See Chin \& Wells, supra note 89, at 249 (quoting the Mollen Commission); Mollen COMMISSION RePORT, supra note 89, at 40.

101. See Mollen Commission Report, supra note 89, at 39.

102. See Capers, supra note 6, at 836-37 (quoting the findings of the Mollen Commission). See also Nicholas Kristof, Was Kevin Cooper Framed for Murder?, N.Y. TIMES, https:/www.nytimes.com/interactive/2018/05/17/opinion/sunday/kevincooper-california-death-row.html [https://perma.cc/Z5D7-6SZY] (last visited Jan. 30, 2019) ("The police are under great pressure to solve a sensational crime, they are sure they have the culprit, and when the evidence is lacking they plant it and give false testimony. This is called 'testilying,' and it's more common than we'd like to think.")

103. See Capers, supra note 6, at 870.

104. See Joseph Goldstein, 'Testilying' by Police: A Stubborn Problem, N.Y. TIMES (Mar. 18, 2018), https://www.nytimes.com/2018/03/18/nyregion/testilyingpolice-perjury-new-york.html [https://perma.cc/JWR2-M8JB] (finding that police lying persists despite increased use of video evidence); see also Donald A Dripps, Police, Plus Perjury, Equals Polygraphy, 86 J. Crim. L. \& CRiminology 693, 699 (1996) (reviewing the work of Richard Uviller who spent eight months observing a New York Police precinct and concluded that most police officers view police perjury as "natural and inevitable").

105. See, e.g., Joseph A. Slobodzian \& Mark Fazlollah, Philly Officer Gets Break on Perjury Charge, Agrees Not to Return to Force, InQUIRER (June 7, 2016), http://www.philly.com/philly/news/20160608_Philly_cop_gets_break_on_perjury_c harge agrees not to return to force.html [https://perma.cc/Y 8 H7- $\overline{\mathrm{N} H \mathrm{DK}}$ ]; Tony Hanson, Heroin Buyer Convicted Despite Testimony from Tainted Phila. Police Officer, CBS PHILly (Aug. 22, 2014), https://philadelphia.cbslocal.com/2014/08/22/ drug-conviction-comes-despite-testimony-from-tainted-phila-police-officer/

[http://perma.cc/Z42T-RXZM] ("When police officers admit to committing perjury and seem to have no fear that this district attorney's office will prosecute them, it degrades the integrity of the entire criminal justice system." (quoting Supervising Attorney Annie Fisher)); Dripps, supra note 104, at 700 (providing that interviews of judges, public defenders, and prosecutors in fourteen criminal courtrooms "outlined a pattern of pervasive police perjury intended to avoid the requirements of the Fourth Amendment. Dishonesty occurs in both the investigative process and the courtroom. The respondents report systematic fabrication in case reports and affidavits for search warrants, creating artificial probable cause which forms the basis of later testimony. Moreover, police keep dual sets of investigatory files; official files and 'street files.' Exculpatory material in the street files may be edited from the official record"); 
Two areas of police testimony seem to breed more perjured testimony than others: attempts to bolster claims of probable cause and attempts to avoid discipline or sanction for wrongdoing, particularly for excessive force claims. ${ }^{106}$ Police perjury notably increased after the Supreme Court decision creating the exclusionary rule in Mapp $v$. Ohio. ${ }^{107}$ In fact, a survey of police officers themselves revealed that $76 \%$ agreed that officers shade the facts to establish probable cause, and that nearly half believed judges were correct when they rejected officer testimony. ${ }^{108}$ This is not a case of "a few bad apples"; it is a pervasive problem in American policing which has been known and largely ignored for decades. ${ }^{109}$

Radley Balko, Walter Scott's Killer is Going to Prison. But His Case Is an Anomaly, WASH. Post (Dec. 8, 2017),

https://www.washingtonpost.com/news/the-watch/wp/2017/12/08/walter-scotts-

killer-is-going-to-prison-but-his-case-is-an-anomaly/?utm_term=.a41ab0e71de0

[https://perma.cc/R2PX-MDX4] (noting that in Los Angeles, "more than 300 sheriff's deputies are on a secret misconduct list for offenses ranging from lying under oath to domestic violence to possible sexual assault. But thanks to union-negotiated rules, that list is kept secret from the public, from defense attorneys and even from prosecutors. Not only were the deputies on the list never criminally charged, they get to keep testifying before juries. They get to keep sending people to prison."); Jacey Fortin, Baltimore Police Officer Charged with Fabricating Evidence in Drug Case, N.Y. TIMES (Jan. 24, 2018), https://www.nytimes.com/

2018/01/24/us/baltimore-officer-video-drugs.html [https://perma.cc/BE2T-SLBD]; Jacey Fortin, Baltimore Drops Dozens of Cases After Video Casts Doubt on Officers, N.Y. Times (Aug. 2, 2017), https://www.nytimes.com/2017/08/02/

us/baltimore-drugs-police-dismissed.html [https://perma.cc/GQ6N-NNP5].

106. See Capers, supra note 6 , at 866 . Additionally, the use of body-cameras has recently documented more and more incidents of police planting false evidence, and many have noted the frequency of testilying in cases where officers plant false evidence or give false testimony in order to "solve" an outstanding crime. See Fortin, supra note 105.

107. See Capers, supra note 6, at 868 (noting the sharp rise in dropsy cases following Mapp once officers realized that telling the truth led to suppression of recovered evidence); see also People v. McMurty, 314 N.Y.S.2d 194, 197 (N.Y. Crim. Ct. 1970) ("So far as I know, there has been only one statistical study of 'dropsy' complaints ... It confirms my impressions: 'In the period after Mapp, the number of complaints alleging that the suspect dropped the contraband increased for all groups of officers."') (quoting Sarah Barlow, Patterns of Arrests for Misdemeanor Narcotics Possession: Manhattan Police Practices 1960-62, 4 CRIM. L. BULl. 549, 556-57 (1968)).

108. See Capers, supra note 6 , at 870 .

109. See Mollen Commission Report, supra note 89, at 1-2 (finding that police supervisors instructed their officers how to lie so that evidence obtained in violation of the Constitution would not be suppressed); Chin \& Wells, supra note 89, at 284 ("[C]ourts have taken divergent approaches to the admission of reports evincing the pervasive nature of the code of silence or conscious ignorance by police 
Perjury and falsification to avoid disciplinary sanctions or criminal charges for police brutality are also common and typically involve offending officers claiming self-defense to justify their excessive use of force. ${ }^{110}$ Other officers either remain silent or support the officers' self-defense claims. ${ }^{111}$ This phenomenon, referred to as

supervisors of their subordinates' behavior."')); Capers, supra note 6, at 868 ('Officers telling 'white lies'-or what this Article terms 'blue lies'-is nothing new. Indeed, blue lies have existed as long as there have been restraints on police activity . . . Nor is perjury any real secret. In the early 1970s the Knapp Commission investigated the NYPD and concluded that corruption was causing officers to testify falsely and prepare false investigative reports. Two decades later, the Mollen Commission was impaneled to study the same problem ... The Commission found a litany of manufactured tales."); See also Morgan Cloud, Judges, 'Testilying, ' and the Constitution, 69 Southern CAlifornia L. Rev. 1341, 1347 (concluding that the avalanche of news reports of police falsification and misconduct in Philadelphia, Los Angeles, Atlanta, New Orleans, Detroit, Minneapolis, and other cities in 1995 "dispels any notion that police misconduct, including perjury, is just a problem in New York or Los Angeles, or any other single location. This is a national problem and has been for decades.") For more recent studies and reports on the continued problem of police falsification see Vida B. Johnson, Bias in Blue: Instructing Jurors to Consider the Testimony of Police Officer Witness with Caution, 44 PEPP. L. REv. 245, 289-91 (2017); Radley Balko, How Do We Fix the Police 'Testilying' Problem?, WASH. PosT (April 16, 2014), https://www.washingtonpost.com/news/the-watch/wp/2014/04/16/ how-do-we-fix-the-police-testilying-problem/?utm_term=.c47190f9d041

[https://perma.cc/NH29-EQ53] (noting that Irving Younger's warning "that the criminal justice system was providing cops with 'heavy incentives to lie in court"” primarily due to the Exclusionary Rule has been repeated "ad nauseam over the years by other judges, defense attorneys, conscientious police chiefs, numerous academics and law journal articles, and whistleblowers."), and Michelle Alexander, Why Police Lie Under Oath, N. Y. TIMES, (Feb. 2, 2013), https://www.nytimes.com/2013/02/03/ opinion/sunday/why-police-officers-lie-under-oath.html [https://perma.cc/URS8LJ77] (quoting Peter Keane, former San Francisco Police commissioner: "Police officer perjury in court to justify illegal dope searches is commonplace. One of the dirty little not-so-secret secrets of the criminal justice system is undercover narcotics officers intentionally lying under oath. It is a perversion of the American justice system that strikes directly at the rule of law. Yet it is the routine way of doing business in courtrooms everywhere in America[,]" and Justice Gustin L. Reichbach of the New York State Supreme Court: "even this court was shocked, not only by the seeming pervasive scope of misconduct but even more distressingly by the seeming casualness by which such conduct is employed.").

110. See Chin \& Wells, supra note 89, at 254-55. ("As a consequence of the code of silence, in cases involving allegations of police misconduct, such as excessive force or brutality, courts may hear boilerplate testimony by police to conceal or justify their malfeasance or that of a fellow officer ... Although this type of police perjury is similar to dropsy testilying, it represents a more blatant variety of perjury, through which officers embrace outrights lies, manufacture evidence, and falsify documents to conceal police abuses or corruption in various forms.").

111. Chin \& Wells, supra note 89, at 237 ("Police officers . . . lie under oath because of the 'blue wall of silence,' an unwritten code in many departments which 
the "blue wall of silence," has been decried as "the greatest single barrier to the effective investigation and adjudication of complaints" against police departments. ${ }^{12}$ Defense attorneys are well-versed with cases in which clients are charged with resisting arrest or assaulting an officer, yet the clients are the only ones with injuries. This has led practitioners and scholars to refer to those types of charges as "cover charges." "13

A recent, high-profile example of a cover charge case is the incident involving Sterling Brown, an African-American NBA player, who was arrested in Milwaukee for resisting or obstructing an officer. ${ }^{114}$ Officers stopped Brown to issue a parking citation, then

prohibits . . . testifying truthfully if the facts would implicate the conduct of a fellow officer."); Levine, supra note 10, at 749 (defining the "blue wall of silence," as when "police either refuse to testify against one another or collude to present their stories in the least criminal light.").

112. See Chin \&Wells, supra note 89, at 240 (quoting the 1991 Report of the Independent Commission on the Los Angeles Police Department - appointed in response to the beating of Rodney King - which found that loyalty obligations and fear of retaliation in police departments served to enforce the officer code of silence). See generally Monroe H. Freedman, The Professional Responsibility of the Prosecuting Attorney, 55 GEO. L.J. 1030 (1967).

113. See Johnson, supra note 109, at 282 (noting some indications of cover charges include when a criminal defendant is charged only with that offense, and no underlying offense justifying the initial interaction by police). An example of cover charges from the author's own criminal defense clinic: A student represented a woman who was charged with resisting arrest after an officer put her head through a wall because she wanted to be present while her minor child was being arrested. The officer put in his police report that this use of force was required because she had unlawfully "entered his personal space." The officer neglected to include the fact that he put her head through a wall and that she was subsequently taken to the hospital by a relative after the incident, all of which was documented by the family and provided to the prosecution. In this particular case the prosecutor dismissed the charges, but notably no actions were taken against the officer. The fact that the officer had charged only resisting arrest, with no other offense that could have justified the arrest in the first place, makes this a typical "cover charge" case.

114. See Nick Bohr, Arrest Report: 'Brown Physically Resisted Officers Attempt to Handcuff Him', ABC News Wisc. (Feb. 7, 2018), https://www.wisn.com/ article/arrest-report-brown-physically-resisted-officers-attempts-to-handcuff-

$\mathrm{him} / 16752938$ [https://perma.cc/92KY-KB4T] (describing the arrest report calling Brown "very aggressive" and explaining "Brown physically resisted officers attempts to handcuff him and he was taken to the ground in a controlled manner" where he continued to "resist being handcuffed" and "a [t]aser had to be employed."); see also Ivan Moreno, Bucks' Sterling Brown Sues Milwaukee over Stun-Gun Arrest for Parking Violation, CHI. TRIB. (June 19, 2018), https://www.chicagotribune.com/sports/basketball/ct-spt-sterling-brown-sues-policearrest-20180619-story.html [https://perma.cc/X436-GAS3] ("The lawsuit alleges officers involved in his arrest used their incident report to try to reframe what 
slammed him to the ground and repeatedly tased him. ${ }^{115}$ The police report states that Brown resisted arrest and was aggressive toward the officers, yet video of the incident does not support that description, and prosecutors declined to pursue charges against Brown. ${ }^{116}$ Brown alleges that the officers discussed the incident shortly after it happened to get their stories straight. ${ }^{117}$ This sequence of events-police brutality, arrest on fabricated charges, and falsification of the police report-is a familiar pattern in these types of cases.

\section{B. Prosecutors Rarely Allege Officer Misconduct Because They Rely on Police Officers as Witnesses}

Prosecutors have several options for dealing with suspected or confirmed cases of officer fabrication: they can bring perjury charges or refer officers who falsify evidence or testimony to Internal Affairs. ${ }^{118}$ They can, and arguably should, share the information with defense attorneys as Brady material. ${ }^{119}$ They can dismiss cases or

happened to give the impression Brown was resisted and obstructed them. ... Brown never appeared to threaten police before or during his arrest, according to police bodycamera videos.").

115. See Moreno, supra note 114.

116. See id.

117. See id. (noting that the bodycam footage supports Brown's claim, as the officers can be heard discussing "protecting themselves" and the likelihood of a media firestorm). Similarly, video footage after the shooting death of Stephon Clark in Sacramento shows officers muting their body-cameras at least sixteen times, leading some to speculate they were discussing how best to limit their exposure to discipline or criminal liability. See Alex Horton, After Stephon Clark's Death, New Videos Show Police Muted Body Cameras at Least 16 Times, WAsh. Post (Apr. 17, 2018, 5:33 PM), https://www.washingtonpost.com/news/post-nation/wp/2018/04/17/afterstephon-clarks-death-new-videos-show-more-muted-police-body-cameras-delays-torender-aid/?utm_term=.7d2b4e493e99 [https://perma.cc/3WW2-UVX4].

118. According to the ABA's Criminal Justice Standards:

While the decision to arrest is often the responsibility of law enforcement personnel, the decision to institute formal criminal proceedings is the responsibility of the prosecutor. Where the law permits a law enforcement officer or other person to initiate proceedings by complaining directly to a judicial officer or the grand jury, the complainant should be required to present the complaint for prior review by the prosecutor, and the prosecutor's recommendation regarding the complaint should be communicated to the judicial officer or grand jury.

Criminal Justice Standards For the Prosecution Function § 3-4.2(a) (AM. BAR Ass'N 2015).

119. See Taylor Pendergrass, How Bad Prosecutors Cause Bad Policing: Prosecuting Abusive Cops is the Least That District Attorneys Can Do, SLATE (Aug. 16, 2016, 2:09 PM), https://slate.com/news-and-politics/2016/08/how-bad- 
decline to call police officers where they suspect that officers have or will falsify testimony or evidence. ${ }^{120}$ Chief prosecutors in particular can mandate that line prosecutors report police misconduct and can provide protected channels for those reports. ${ }^{121}$

Unfortunately, prosecutors rarely exercise these options. ${ }^{122}$ When they do, they tend only to decline calling the suspect officer as a witness. ${ }^{123}$ This of course does little to change behavior or deter falsification and contributes to the overall culture of impunity surrounding police misconduct. ${ }^{124}$ Thus, police perjury may be tolerated, or even encouraged, by prosecutors at each step in the process in both direct and indirect ways. ${ }^{125}$ A major reason for this tolerance is the degree to which prosecutors depend on police officers to investigate criminal activity, provide evidence, and testify at motions and trials. State prosecutors generally do not direct the actions

prosecutors-cause-bad-policing.html [https://perma.cc/BV9Q-VQVL]. But see Jonathan Abel, Brady's Blind Spot: Impeachment Evidence in Police Personnel Files and the Battle Splitting the Prosecution Team, 67 Stan. L. ReV. 743, 743 (2015) (arguing that prosecutors themselves are often precluded from obtaining or disclosing the contents of police personnel files by statute, local rule, and police policy and union action); Gonnerman, supra note 98 (chronicling the difficulty that even the District Attorney of Philadelphia has had in obtaining information from IAD regarding officer complaints).

120. See Pendergrass, supra note 119; see also CRIMINAL Justice StANDARdS For the Prosecution Function § 3-1.4(b) (AM. BAR Ass'N 2015). The Prosecutor's Heightened Duty of Candor states that "the prosecutor should not make a statement of fact or law, or offer evidence that the prosecutor does not reasonably believe to be true," and establishes a continuing duty to correct any other representations made by other prosecutors that one later learns to be or reasonably believes to be false.

121. See Pendergrass, supra note 119.

122. See Michael Bloch, When Cops Lie Under Oath, Prosecutors Must Take Some Blame, USA TodAY (Feb. 22, 2018, 7:01 PM), https:/www.usatoday.com/ story/opinion/policing/2018/02/22/when-cops-lie-under-oath-prosecutors-must-takesome-blame/360414002/ [https://perma.cc/YMG3-63N6] (noting that prosecutors often seek to conceal records of prior police misconduct from defense attorneys and the Court and rarely dismiss cases based on disbelief of officer testimony).

123. In Philadelphia, this practice created what became known as the "do not call" list. See Alicia Victoria Lozano, 29 Problem Police Named in Philadelphia District Attorney's 'Do Not Call' List, NBC PHILA. (Mar. 7, 2018), https://www.nbcphiladelphia.com/news/local/29-Problem-Cops-Named-inPhiladelphia-District-Attorneys-Do-Not-Call-List-476133573.html [https://perma.cc/28WL-G9VZ] (describing the list as an "internal guide to determine when a potentially tainted officer's testimony could be used," and listing offenses of the former and current officers on the list as including "lying to police investigators, filing false police reports, use of excessive force . . . among other issues.").

124. See Capers, supra note 6, at 866.

125. See id. at 850 . 
or investigations of police departments. This makes them dependent on the cooperation of officers to make out their cases ${ }^{126}$ and creates a vested interest in "maintaining smooth working relations with police, who gather the government's evidence and are often its most important witnesses at trial." ${ }^{127}$ This dependency dramatically decreases the degree to which prosecutors are willing to reject officer testimony, pursue misconduct claims against officers, or challenge police narratives. ${ }^{128}$

The problem is exacerbated by an overreliance on police narratives by the prosecutors who are least equipped to challenge them. Misdemeanor court is a common starting ground for newer prosecutors. It is also the place where many cases are litigated without any civilian witnesses or complainants. ${ }^{129}$ This means it is most often newer prosecutors who are heavily or entirely reliant on officer testimony to prosecute their cases and who are regularly handling cases in which the only question for the court is the officer's credibility. More experienced prosecutors are more likely to be handling more serious cases - robberies, assaults, sexual offensesthat tend to involve more civilian complainants and witnesses. Thus, the people most likely to be put in the position of having to question the testimony of an officer are often the people least equipped to do so.

In cases where officer credibility is the only issue for the court, a defense attorney has no option but to attack the truthfulness of the

126. See David A. Harris, The Interaction and Relationship Between Prosecutors and Police Officers in the U.S., and How This Affects Police Reform Efforts 2-3 (Univ. Pitt. Sch. of Law, Legal Studies Research Paper Series, Working Paper No. 2011-19, 2011). See generally EriK Luna \& Marianne L. Wade, The Prosecutor in Transnational Perspective (2012).

127. Jay Sterling Silver, Truth, Justice, and the American Way: The Case Against the Client Perjury Rules, 47 VAND. L. REV. 339, 358 n.75 (1994).

128. See Capers, supra note 6, at 874 . Capers sums up the relationship as follows: "Prosecutors need cases. Officers make cases. A priori, prosecutors need officers." See also Daniel Richman, Prosecutors and Their Agents, Agents and Their Prosecutors, 103 Colum. L. REv. 749, 792 (2003) ("[O]ne ought not underestimate the unifying influence of a shared commitment to 'getting the bad guys,' hardened by the adversarial process, nurtured by mutual respect and need, and on occasion lubricated by alcohol.").

129. Common misdemeanor cases include charges such as drug possession, resisting arrest, disorderly conduct, prostitution, criminal mischief, and-in some jurisdictions - traffic offenses. Most of these cases involve only police witnesses, thus making the prosecutors entirely dependent on police testimony to prove the elements of the offense. 
officer's statement. ${ }^{130}$ For example, if the officer's testimony is that she recovered illegal drugs from the defendant's pocket, the defense must argue that either the officer is mistaken, or she is lying. If the officer is telling the truth, the defendant is guilty. Once the officer's credibility is attacked, the prosecutor - if he still intends to win the case - is then in the position of defending the officer's story. The prosecutor may point to the physical evidence that supports the officer's testimony. He may also argue motive and assert that, because the officer does not know the defendant, she cannot have any bias toward him and therefore the factfinder can assume that she is telling the truth. ${ }^{131}$ This line of argument plays on the disinclination of judges to call police officers liars and the natural inclination of most Americans to believe the police. ${ }^{132}$ It also demands that any motive behind police violence be personal and arise out of animus toward the defendant as an individual, despite the large role implicit bias can play in policing decisions. ${ }^{133}$

\section{Police Claims of Self-Defense to Justify Deadly Force Implicate Narratives of Black Criminality and Dangerousness}

Concerns about police falsification and the ways in which prosecutor complicity contributes to the degradation of the legitimacy of the justice system are heightened in cases involving minority victims of police abuse because of the historical legacy of racially discriminatory policing. ${ }^{134}$ The dehumanization of people of color in the United States, first used to justify and enable slavery and later to

130. Note, the decision to go to trial lays solely with the defendant, not the defense attorney. Because of the duty to zealously represent one's client, a defense attorney in a trial on those allegations would have to argue either mistake or falsification.

131. See discussion of State v. Stockley, No. 166-CR02213-01, slip op. at $\mathrm{x}$ (22d Jud. Cir. Ct. Sept. 15, 2017) infra Section II.D (discussing the judge's conclusion that the lack of a preexisting relationship between the parties precluded any possibility of motive).

132. See Capers, supra note 6, at 875 n.214 ("Judges are often reluctant to make adverse credibility determinations against an officer 'on the record.' Instead, judges tend to grant suppression motions on the 'more acceptable' ground that, even crediting the officer's testimony, the evidence was insufficient to establish reasonable suspicion or probable cause.”); see also Chin \& Wells, supra note 89, at 246 (stating that jurors interviewed after police credibility trials will often say things like, "we just couldn't think of any reason why the police officers would go to the trouble of making up a story and framing someone.") (internal quotations omitted).

133. See infra Section II.C.

134. See Lee \& Ifill, supra note 7, at 255-56. 
rationalize the disparate treatment of African Americans under Jim Crow, has created deep-seated associations of race and dangerousness in the American psyche. ${ }^{135}$ While overt racism certainly persists today and in fact appears to be increasing, ${ }^{136}$ still more common are the implicit biases, stereotypes, and assumptions that shape decisionmaking, often unwittingly. ${ }^{137}$ Neurologically, racially coded categories create neural pathways that become entrenched over time, ultimately encouraging "rapid unconscious thinking that has the effect of hardwiring stereotypes into the pathways of the brain." 138 The more one is exposed to these narratives, the more strengthened the neural synapse circuits associated with these stories become, eventually becoming a permanent part of the brain's structure. ${ }^{139}$ These

135. Id. at 260. ("At the heart of this discrimination is the automatic association between 'blackness' and criminality that is the product of the longstanding dehumanization of black people throughout American history"); see also Brent Staples, The Racist Trope that Won't Die, N.Y. TIMES (June 17, 2018), https://www.nytimes.com/2018/06/17/opinion/roseanne-racism-blacks-apes.html [https://perma.cc/A54A-V76Q] (citing the work of Jennifer Eberhardt and Phillip Atiba Goff and arguing that "[t]his process of dehumanization often leads Americans to view African-American men as larger and more fearsome than they are"). Dehumanizing rhetoric and faux science have been used throughout history against countless groups to inspire animus and violence - by early white settlers against American Indians to justify cultural genocide, by the Nazi party against European Jews, and now by the United States government against Latinx migrants. The dehumanization of Native Americans and Latinxs have had similar impacts on the ways in which these communities are policed. This Article focuses primarily on stereotypes of black criminality in order to engage with some of the specifics of the narratives.

136. The FBI 2016 annual Hate Crime Statistics found that hate crimes rose nearly $5 \%$ in 2016. See U.S. DeP'T OF Justice, FBI Uniform CRIME RePORT: Hate CRime Statistics, 2016 (2017). There were 5,850 hate crimes reported in 2015 and 6,121 reported in 2016. Id. More than 50\% of those crimes are directed against African Americans. Id. The 2017 Report showed law enforcement reporting 7,175 hate crimes to the Uniform Crime Reporting Program, an increase of approximately $17 \%$ from 2016. Approximately 5,000 of those crimes were categorized as crimes against persons, and just under $60 \%$ were categorized as incidents involving race/ethnicity/ancestry bias. See U.S. DeP'T OF Justice, FBI Uniform CRIME RePORT: Hate Crime Statistics, 2017 (2018).

137. See Chris Mooney, The Science of Why Cops Shoot Young Black Men, MOTHER JONES (Dec. 1, 2014, 11:00 AM), https://www.motherjones.com/politics/ 2014/12/science-of-racism-prejudice/ [https://perma.cc/3X38-QGQZ].

138. Lucy Jewel, Neurorhetoric, Race, and the Law: Toxic Neural Pathways and Healing Alternatives, 76 MD. L. REV. 663, 664 (2017) ("Neuroscience explains why and how racially coded categories are so efficient: they create neural pathways that, upon continued use, become collectively entrenched.").

139. Id. at 674 ("Repeated exposure to certain forms of narrative rhetoric causes the neural synapse circuits associated with these stories to become so strong 
stereotypes are prevalent in the media, which regularly, and often exclusively, depicts people of color as dangerous criminals. ${ }^{140}$

Police officers, like most Americans, exhibit common implicit biases about African-American males. ${ }^{141}$ Americans typically view men and boys of color as inherently more dangerous and their behavior more criminal than white men and boys. ${ }^{142}$ While these assumptions are not unique to the police, they are more likely to manifest in the types of split-second decisions made by police officers encountering someone they have identified as a suspect. ${ }^{143}$ Prosecutors may share these implicit biases and be influenced by them when pursuing charges against defendants of color. The more stories invoking these narratives are told, the more embedded in the national psyche they become. It is in this way that individuals' have become primed to receive and believe the narratives of police officers who claim self-defense after killing black men.

that they form a permanent part of the brain's structure. In this way, deep narratives become implanted.").

140. In the context of crime coverage, there is considerable evidence that media primarily and often exclusively portray black and Latinx Americans as violent criminals. See Entman \& Gross, supra note 91, at 97.

141. See Mooney, supra note 137. Implicit bias "refers to attitudes and beliefs that individuals do not consciously control." Katheryn Russell-Brown, Making Implicit Bias Explicit: Black Men and the Police, in POLICING THE BLACK MAN 138 (Angela J. Davis ed., 2017) (citing various studies showing bidirectional links between perceptions of criminality and blackness and identifying three major themes from the research: police respond in a racially biased way toward black targets, police shoot more quickly at a black armed target than a white armed target, and police are more likely to mistakenly believe that a black target is armed than that a white target is).

142. See id. at 144 (noting study by Joshua Correll using video game simulation to test responses to shooter simulations which showed that civilians were more likely than officers to shoot unarmed black targets and more likely overall to shoot black targets than white targets). Notably, research shows that police officers, as a whole, display less implicit bias toward suspect of color than the average American civilian. Id. at 145 ("The community members were more likely than the officers to shoot unarmed black targets. The researchers also found that community members were overall more likely to shoot black targets than white targets.")

143. Lee \& Ifill, supra note 7, at 278 ("These automatic, yet baseless, associations between race and dangerousness - derived from generations of false and dehumanizing stereotypes of blackness - are even more likely to occur when making the type of 'split-second judgments' that the Supreme Court acknowledged were common for police officers."). 


\section{Pro-Police Narratives Hurt Prosecutors When Prosecuting Police}

Despite the frequency of police perjury, ${ }^{144}$ the interplay of neuroscience and unchallenged stock narratives continue to result in deference to police testimony. ${ }^{145}$ Stock narratives of black criminality and the inherent dangerousness of black men prime fact finders to believe the types of self-defense narratives often told by police in cases where they have shot and killed victims of color. These narratives are compounded by many routine prosecutorial practices. The conviction-motivated mindset of prosecuting offices encourages the practice of overcharging defendants, which fuels higher rates of guilty pleas and fewer litigated suppression motions. ${ }^{146}$ People of color, and particularly indigent people of color, are vastly overrepresented in the American criminal system in comparison to their white peers, who exhibit similar offense rates for most crimes. ${ }^{147}$

144. It is important to note that while much of the public is unaware of the frequency of police perjury because of the failure to address it; poor communities of color have lived with its consequences for decades. Chin \& Wells, supra note 89, at 249-50 ("The defendant knows that the police lied. The defendant's friends, family and neighbors may well believe him when he says 'I did it, but the police lied on me.' Seeing members of one's community sent to prison based on solemn lies undermines belief in the very legitimacy of the law.").

145. Lucy Jewel describes this as follows: "In any criminal proceeding, a simple reference that a legal actor is a black male with a firearm is likely to trigger deep-seated neural pathways related to fear." Jewel, supra note 138, at 681 . If the fact finder him or herself is experiencing fear, it makes it much easier to believe it reasonable that the defendant was likewise fearful-even if fear would be an objectively unreasonable reaction under the circumstances.

146. See generally John Pfaff, Locked In: The True Causes of INCARCERATION AND HOW TO ACHIEVE REAL REFORM (2017) (noting increased rates of felony charges fueling mass incarceration). Kate Levine and the work of Josh Bowers identify the charging decision as among the most important made by prosecutors. E.g., Josh Bowers, Legal Guilt, Normative Innocence, and the Equitable Decision Not to Prosecute, 110 Colum. L. REV. 1655, 1709 (2010) (“[P]rosecutors' initial decisions of what and whether to charge are somewhat dispositive on the question of whether the defendant will ultimately end up with some type of conviction ....").

147. See generally NATAPOFF, supra note 71 (noting that offending and arrest rates among citizens are particularly disparate in the misdemeanor system); See also AlEXANDER, note 71; Capers, supra note 6, at 850 ("The Maryland Report found that the hit rates for blacks who had been stopped and searched was in fact statistically identical to the hit rates for whites who had been stopped and searched: the hit rate for when officers searched black motorists was $28.4 \%$; the hit rate when officers searched white motorists was $28.8 \%$. The results of a study conducted by the New Jersey State Police in 2000 are even starker. The New Jersey study found that blacks and Hispanics comprised seventy-eight percent of the motorists stopped and searched. In terms of 
This is generally attributed to the over-policing of people of color, particularly in the implementation of police practices such as stop and frisk. ${ }^{148}$ Despite the fact that stop-and-frisk practices yield incredibly low success rates for contraband, judges see only the small fraction of cases in which contraband is found. ${ }^{149}$ Because most of these cases are resolved by way of guilty plea, judges then see defendants who may in fact be innocent or have viable suppression motions ${ }^{150}$ pleading guilty. ${ }^{151}$ Not only does this process obscure wrongdoing by police, ${ }^{152}$ it also perpetuates a belief among fact finders that police narratives are inherently reliable. Prosecutors play into this belief when they attest to officer credibility in suppression motions and trials. In so doing, prosecutors may-intentionally or not-perpetuate the pro-police narratives that discredit narratives of people of color and ultimately disadvantage prosecutors when trying to convict a police officer in a cross-racial shooting. ${ }^{153}$ These dynamics can be seen in the case of Jason Stockley, a St. Louis police officer who was charged with first-

hit rates, the troopers found evidence of criminal activity in thirteen percent of their searches of black motorists, and in five percent of their searches of Hispanic motorists. By contrast, when officers searched white motorists, they found evidence of criminal activity twenty-five percent of the time. Similar studies in other jurisdictions have produced similar data.").

148. See K. Babe Howell, Prosecutorial Discretion and the Duty to Seek Justice in an Overburdened Criminal Justice System, 27 GEO. J. LeGAL ETHICS 285, 297 (2014); Capers, supra note 6, at 851 ("For example, NYPD citywide stop and frisk data between 1998 and 2000 revealed that eighty-four percent of the individuals stopped and frisked in New York City were black or Hispanic. Between 1997 and 1998, NYPD's elite street crime unit conducted nearly 40,000 frisks that revealed no contraband at all.").

149. See Howell, supra note 148, at 297; Capers, supra note 6, at 851, 880; see also Floyd v. City of New York, 959 F. Supp. 2d 540, 556 (S.D.N.Y. 2013) (discussing the stark racial disparities and low success rates that characterize stop and frisk policing); Tim Lynch, The Devil's Bargain: How Plea Agreements, Never Contemplated by the Framers, Undermine Justice, CATO InST. (July 2011), https://www.cato.org/publications/commentary/devils-bargain-how-plea-

agreements-never-contemplated-framers-undermine-justice [https://perma.cc/8G7KD5R8].

150. See Howell, supra note 148, at 292.

151. For a truly demoralizing description of how the criminal system extracts guilty pleas from innocent people and the ways in which people of color are particularly vulnerable to these injustices, see NATAPOFF, supra note 71, at 87-111.

152. See Lynch, supra note 149.

153. Adamson, supra note 91, at 5 ("Overall, the inherent text and subtext of crime news perpetuates skepticism toward Black narratives and legitimacy toward majoritarian, law enforcement orthodoxies. Those racialized narratives have been shown to have adverse impacts upon jurors and defendants."). 
degree murder in the spring of 2016 for shooting and killing Anthony Lamar Smith. ${ }^{154}$

The incident occurred on December 20, 2011, after Stockley and his partner engaged in a high-speed chase of Smith's car. ${ }^{155}$ During the pursuit, Stockley fired at the car multiple times and was recorded saying, "We're killing this motherfucker, don't you know."156 His partner rammed Smith's car to end the chase. ${ }^{157}$ Stockley then approached Smith's window and fired five times, killing Smith. A gun was recovered from Smith's glove compartment, which the prosecutor submitted Stockley had planted to bolster his self-defense claim. Supporting the prosecutor's argument was the fact that the only DNA recovered from the gun belonged to Stockley. Nonetheless, Stockley was acquitted. The judge who presided over the bench trial released an opinion supporting his verdict, making the case a unique opportunity to see how prosecutor complicity with police perjury works against the state in police prosecutions.

The judge's opinion echoed many of the kinds of pro-police arguments regularly used by prosecutors in cases where defense attorneys challenge the credibility of the testifying officer. First, the judge noted that there was no preexisting relationship between Stockley and Smith, meaning that there was no motive for Stockley to kill Smith. ${ }^{158}$ The question of motive is certainly relevant in a homicide but by requiring that animus be both overt and personal, the judge ignores the reality of how implicit bias shapes and informs police decision-making. ${ }^{159}$

Second, the judge concluded that the firearm recovered from the glove compartment belonged to the victim, Anthony Lamar Smith, noting that "an urban heroin dealer not in possession of a firearm would be an anomaly." 160 The judge specified that this is based on what

154. See Complaint at 1, State v. Stockley (22d Jud. Cir. Ct. Sept. 15, 2017) (No. 166-CR02213-01).

155. See id. at 2 .

156. See id.at 5 .

157. See id.

158. State v. Stockley, No. 166-CR02213-01, slip op. at 20-21 (22d Jud. Cir. Ct. Sept. 15, 2017) ("The Court believes it is significant that defendant Stockley and Smith did not know each other prior to December 20, 2011, they had no prior history, there was no history between Stockley and members of Smith's family, and there was no basis in the evidence to suggest any pre-existing animosity by Stockley toward Smith.").

159. See generally L. Song Richardson, Police Racial Violence: Lessons from Social Psychology, 83 FordHAM. L. REV. 2961 (2015).

160. Stockley, slip op. at 26 (22nd Jud. Cir. Ct. Sept. 15, 2017). 
he has learned presiding over criminal trials - in other words, what he has previously heard in police testimony. ${ }^{161}$ His thirty years on the bench have doubtless offered a myriad of opportunities to listen to police officers testify at trials about "urban heroin dealers" and their practices and to oversee countless guilty pleas from such defendants. ${ }^{162}$ The perception of criminal activity for many judges is shaped by what they see in their courtrooms: defendants of color pleading guilty, allowing judges to conclude that the police were right to stop them. The true numbers, however, tell a wholly different story. ${ }^{163}$ The judge's reliance on past courtroom experience to conclude that Smith was an "urban heroin dealer" and must have possessed a firearm thus raises concerns of confirmation bias. ${ }^{164}$

161. Id. slip. op. at 26. ("Finally, the Court observes, based on its nearly thirty years on the bench, that an urban heroin dealer not in possession of a firearm would be an anomaly.") The notion that "guns follow drugs" is fairly pervasive in the criminal justice system and has been for some time. See JAMES Forman JR., LocKING Up OuR OwN 165 (2017) (noting D.C. Mayor Marion Barry's tendency to use the phrase "gun thugs and drug thugs" to justify harsher police tactics). This automatic presumption that guns follow drugs was specifically disallowed by the Supreme Court of Pennsylvania in Commonwealth v. Grahame, 7 A.3d 810, 811 (Pa. 2010) (holding that the Superior Court erred in adopting a "guns follow drugs" presumption in order to justify a protective search for weapons simply because drug activity was present).

162. Here we see how the typical prosecutorial function in the retributive system-pleading out cases regardless of constitutional violations, officer falsification, or actual innocence - can create a confirmation bias for factfinders. See Howell, supra note 148, at 295-96; see also Floyd v. City of New York, 959 F. Supp. 2d 540, 556, 558-59 (S.D.N.Y. 2013); Lynch, supra note 149.

163. See Floyd, 959 F. Supp. 2d at 556, 558-59 (finding that of the 4.4 million stops made by the NYCPD between 2004 and 2012, over $80 \%$ were of AfricanAmerican or Hispanic individuals; in $98.5 \%$ of the 2.3 million frisks for weapons, no weapon was found; in $86 \%$ of searches, no contraband was found; and in $88 \%$ of stops overall, no arrest or other law enforcement action resulted). Capers, supra note 6 , at 851 ("For example, NYPD citywide stop and frisk data between 1998 and 2000 revealed that eighty-four percent of the individuals stopped and frisked in New York City were black or Hispanic. Between 1997 and 1998, NYPD's elite street crime unit conducted nearly 40,000 frisks that revealed no contraband at all."); See also, Marc Mauer, The Endurance of Racial Disparity in the Criminal Justice System, in Policing THE Black MaN 42 (discussing data from New Jersey, Maryland and Florida showing that black motorists were stopped far more often than other motorists and that "hit rates" resulting from searches failed to show that black drivers were more likely to be carrying contraband than any other drivers, as well as discussing New York's data showing that, while black and Latinx New Yorkers were more likely to be frisked during a pedestrian stop, they were only half as likely to be found in possession of an illegal weapon, and that of the 191,000 stops in 2013 in New York, guns were found in less than $1 \%$ of all cases).

164. According to the judge's opinion, a bag of heroin was recovered from the vehicle that Smith was driving, which had Mr. Smith's DNA on it. The other occupant 
Third, the judge found that the defendant's testimony needed no corroboration to be believed. ${ }^{165}$ This unusual statement seems emblematic of the double standard for police defendants - particularly the heightened presumption of innocence. ${ }^{166}$ Generally, a defendant's testimony raises questions because of his or her self-interest in avoiding a conviction. ${ }^{167}$ In this case, Stockley had a clear motive to fabricate a claim of self-defense: If he was not acting in self-defense, he was guilty of homicide. The judge, in ignoring this obvious motivation, seemed to bend over backwards to award credibility points to a police officer, reflecting the common prosecutor argument that police credibility is unassailable. ${ }^{168}$ It seems impossible to envision the same presumption of credibility being given to a nonofficer defendant like the victim, an "urban heroin dealer," had he been the one on trial.

This acquittal was perceived as a failure to deliver justice to the victim, his family, and the community, undermining their sense of the

of the vehicle, Mr. Taylor, testified that he was unaware that heroin was in the car. The judge found his testimony not credible. Stockley, slip op. at 11 . The judge does not mention any evidence that Mr. Smith was engaged in drug dealing other than Stockley's testimony that Mr. Smith was engaged in "suspicious activity" and was involved in a "perceived drug transaction." Stockley, slip op. at 14. The judge excluded proffered evidence that Anthony Smith had prior felony convictions. Thus, his conclusion that Mr. Smith was an "urban heroin dealer" appears to be based solely on the presence of heroin and the statement by Jason Stockley that he observed Mr. Smith in an alleged drug transaction. This conclusion raises additional concerns of victim-blaming that are often present in these cases.

165. See Stockley, slip op. at 26.

166. Lee \& Ifill, supra note 8, at 279-80.

167. See Johnson, supra note 109, at 249 (noting that in most jurisdictions, when a criminal defendant testifies, the jurors are instructed that because he or she has a "vital" interest in the outcome the jurors may afford the testimony less weight). This jury instruction has been criticized for conflicting with the presumption of innocence, and it is not the intention of this author to argue in its favor. Rather, it is included to note just how surprising it is for the judge in this matter to find that the defendant's testimony was so inherently trustworthy that he drew no conclusions from the failure of his partner to testify.

168. See id. at 257. This desire to protect the reputation of police officers' testimony as credible goes back decades. See id. (citing Bush v. United States, 375 F.2d 602, 604 (D.C. Cir. 1967)) (noting that courts have long been resistant to give jury instructions indicating that police officers may be motivated to lie in the prosecution's favor, culminating in the decision in Bush v. United States which found that "it would be a dismal reflection on society to say that when the guardians of its security are called to testify in court under oath their testimony must be viewed with suspicion"). 
law's legitimacy. ${ }^{169}$ It permitted Stockley to persist in his state of denial, stating in a post-trial interview, "I know everyone wants someone to blame, but I'm just not the guy." 170 This statement is remarkably similar to that made by former Tulsa police officer Betty Shelby after her acquittal for the shooting death of Terence Crutcher: "I did everything I could to stop this . . . Crutcher's death is his fault." ${ }^{171}$ Both officers claimed self-defense during their trials despite, in Shelby's case, the victim indisputably being unarmed and posing no immediate threat. ${ }^{172}$ This continued denial should not be surprising. For these officers, legal and societal acceptance of their self-defense claim validates their belief - whether conscious or unconscious - that the black man they killed was inherently dangerous, allowing them to eschew not only legal but also moral wrongdoing. It sends the same message to the public. ${ }^{173}$

169. Following Jason Stockley's acquittal, Anthony Lamar Smith's brother was interviewed and asked what he thought of the verdict. His answer: "These laws are not made for us. They not. They made for y'all. Ten years from now all the little kids. . they going to be saying I want to grow up to be a police-I can kill a black person and I'm gonna get away with it." See Taryn Finley, Anthony Lamar Smith's Brother: The Justice System Doesn't Care About Us, HuffPost (Sept. 15, 2017), https://www.huffingtonpost.com/entry/anthony-lamar-smith-brother-st-

louis_us_59bc1740e4b0edff971bdab1 [http://perma.cc/P6Q4-GCBE]. At the same time, there were protests on the streets of St. Louis, during which police officers in riot gear could be heard chanting, "Whose streets? Our streets!" at demonstrators. See AJ Willingham, How the Iconic 'Whose Streets? Our Streets!' Chant Has Been CoOpted, CCN (Sept. 20, 2017), https://www.cnn.com/2017/09/19/us/whose-streetsour-streets-chant-trnd/index.html [http://perma.cc/7HD6-B925]; see also Vida B. Johnson, Prosecutors Who Police The Police Are Good People, 87 FordHAm L. REV. ONLINE 13, 16 (2018) ("The failure to police the police undermines the community's trust in law enforcement and other criminal justice institutions, especially in light of the vigor with which prosecutors prosecute the most vulnerable in our society.").

170. Protesters Take to the Streets in St. Louis in Response to Officer Jason Stockley Being Found Not Guilty of the Murder of Anthony Lamar Smith, CNN (Sept. 15, 2017), http://transcripts.cnn.com/TRANSCRIPTS/1709/15/cnnt.01.html [https://perma.cc/GEN8-HVQJ]. When asked why he agreed to be interviewed about the incident, Stockley replied, "Because I didn't do anything wrong." Christina M. Fletes, Video: Exclusive Interview with Jason Stockley after His Acquittal, ST. LouIS Post-DisPatch (Sept. 15, 2017), https:/www.stltoday.com/news/local/metro/videoexclusive-interview-with-jason-stockley-after-his-acquittal/html_1848b1cd-30bd-

5567-995c-bd26e9e66a29.html [http://perma.cc/8BKX-XPYG]

171. Erik Ortiz \& Phil Helsel, Jury Acquits Tulsa Officer Betty Shelby in Shooting Death of Terence Crutcher, NBC NEws (May 18, 2017), https://www.nbcnews.com/news/us-news/jury-acquits-tulsa-officer-shooting-deathterence-crutcher-n761206 [http://perma.cc/R7TQ-HSM2].

172. See id.

173. Kay Nolan \& Julie Bosman, Milwaukee Officer Is Acquitted in Killing of Sylville Smith, N.Y. TIMES (June 21, 2017), https://www.nytimes.com/2017/06/ 
The inherent challenges of the Stockley case for the prosecution are exacerbated by the everyday decisions of prosecutors in cases that involve routine complicity with police perjury. ${ }^{174}$ The failure of prosecutors to challenge police narratives leaves intact unconscious tropes linking blackness with criminality, which ultimately take on a life of their own, embedding in the minds of fact finders and making the prosecution of police nearly impossible. ${ }^{175}$

\section{More RESTORATIVE PROSECUTION PRACTICES COULD DECREASE RELIANCE ON POLICE TESTIMONY, INCREASE DIVERSITY OF NARRATIVES IN THE PUBLIC SPHERE, AND IMPROVE PROSECUTION OF OFFICER MISCONDUCT}

Law Professor Seth Stoughton, a former police officer, has argued that law enforcement has a "Warrior" problem. ${ }^{176}$ Stoughton argues that shifting the policing model from the archetype of the Warrior to the archetype of the Guardian would necessarily change the behavior of police officers because it would change their objectives

21/us/milwaukee-police-shooting-trial-protest.html [http://perma.cc/6S3C-UA4K]. "I feel like no matter what it is, these police officers all over the world, they can just literally murder you," said a stepsister, Shannon Daniels. Id. "I feel he blatantly shot Sylville. I feel it was intentional." Id.

174. This case is by no means the cleanest example of these difficulties. The testimony of eyewitnesses and the decision to charge Stockley with first-degree homicide (such that prosecutors were required to prove premeditation) did not make this an easy or simple case for the prosecution. It is included primarily because the written opinion accompanying the verdict offers some insight into the fact finder's reasoning.

175. They also leave prosecutors vulnerable to attack. When former Tulsa, Oklahoma, police officer Betty Shelby was on trial for shooting and killing Terence Crutcher, an unarmed black man, during a traffic incident, her defense attorney focused his closing argument on the prosecutor's hypocrisy. See Dylan Goforth, Jurors Begin Deliberating as Attorneys Close in Betty Shelby Trial, FrONTIER (May 17, 2017), https:/www.readfrontier.org/stories/jury-begins-deliberating-attorneysclose-betty-shelby-trial/ [https://perma.cc/DJ6N-VL28]. He told the jury that the prosecutor regularly calls officers as reliable witnesses in his other cases but nonetheless "has the audacity to come in here and tell you that law enforcement officers will come in here and lie to protect Betty Shelby." Id. Evidence of the blue wall of silence indicates that was quite likely, but nonetheless the argument was apparently effective.

176. See Seth Stoughton, Law Enforcement's Warrior Problem, 128 HARV. L. REV. F. 225, 225 (2014-2015) (arguing that American police officers are trained to think of themselves as warriors pitted against an enemy, and that this worldview contributes to a high number of negative interactions between officers and civiliansparticularly civilians of color). 
when interacting with citizens. ${ }^{177}$ Perhaps the same fundamental shift is needed for prosecutors. American prosecutors embody a nearly impossible role in the justice system. They are required to seek justice for all parties while also making up one side of an adversarial system. ${ }^{178}$ Prosecutors understandably become attached to their complainants and cases and, particularly in high-stakes felony trials, to obtaining convictions. This creates what could be called an "Adversary" problem. ${ }^{179}$ Like the Warrior, the Adversary is a problematic archetype for the American prosecutor, as is the archetype commonly associated with high-volume misdemeanor practice - the "Case-Processor." 180

Fortunately for prosecutors, the American Bar Association (ABA) has identified a potential alternative model to replace these paradigms. The ABA Criminal Justice Standards for the Prosecution Function states that " $[\mathrm{t}]$ he prosecutor is not merely a case-processor but also a problem-solver responsible for considering broad goals of the criminal justice system." 181 A Problem-Solver mentality necessarily takes a more holistic approach to criminal justice, looking for true solutions to both the problems created by an offense and the

177. See id. at 226.

178. See Criminal Justice Standards for the Prosecution Function § 31.2 (AM. BAR ASS'N 2015).

179. See Levine, supra note 10, at 758 (indicating that line prosecutors are often promoted due to their success at obtaining convictions, and district attorneys run for reelection on their "tough on crime" stance).

180. See § 3-1.2; Natapoff, supra note 17, at 257. It should also be noted that the vastly different funding applied toward prosecution offices versus indigent defense offices make the "Adversary" role particularly difficult to justify. See PFAFF, supra note 146 (noting that some states paid three times as much for prosecution as toward the state indigent defense funding). There will still be a place for prosecutors to act as the Adversary in the criminal system. The bulk of this Article has been devoted to the times when such a role is required by the state and the publicspecifically, crimes of violence where the alleged perpetrator denies wrongdoing. The importance of this role is heightened where the victim is a member of a marginalized, oppressed, or vulnerable group. Similarly, Stoughton is careful to note that the Warrior mentality does have a role in policing, specifically when officers are put in that position to protect themselves or, more importantly, others. See Stoughton, supra note 167 , at 225 .

181. $\S 3-1.2(\mathrm{f})$. This is similar to the language Howard Zehr uses in detailing a restorative approach to justice: "[L]awyers (including prosecutors) would envision themselves less as gladiators out to win than as healers and problem-solvers." ZEHR, supra note 17 , at 77 . 
problems underlying it. ${ }^{182}$ In other words, it embraces some of the fundamental principles of restorative justice. ${ }^{183}$

Prosecutors can embody the Problem-Solver archetype by using restorative practices to drive decision-making. In order to support these efforts, voters should elect candidates for District Attorney who support restorative practices and will instill in their offices a less adversarial approach to justice. The electorate has already started electing some District Attorneys who are making drastic changes to their offices, including the institution of more restorative-based decision-making. ${ }^{184}$ Law schools should support these efforts by increasing clinic offerings in prosecution to give burgeoning prosecutors an opportunity to engage in best practices thoughtfully and diligently outside of the Case-Processor approach that defines the work of most young prosecutors.

\section{A. Shifting to Restorative-Driven Decision-Making Would Encourage Prosecutors to Act as Problem-Solvers as Opposed to Adversaries}

Decreasing prosecutor complicity with police perjury and propolice narratives requires decreasing the dependency of prosecutors on police officers as witnesses. ${ }^{185}$ Although much of this Article has addressed the strengths of and need for formal retributive justice in the case of police shootings, this Section explores a proposal that may seem counterintuitive: that one way to increase the success of police prosecutions is to use more restorative justice practices in the retributive criminal system. ${ }^{186}$ Currently, the primary framework for prosecutorial decision-making is retributive, as the primary questions prosecutors use as a guide are those that define a retributive system:

182. See § 3-1.2(f).

183. See ZEHR, supra note 17, at 22-25.

184. See Gonnerman, supra note 98.

185. See supra Part II.

186. FORMAN, supra note 161, at 236-37 ("What if we came to see that justice requires accountability, but not vengeance?" ... What if we endeavored to make the lives of black victims matter without policies that lead to the mass incarceration of black defendants? What if we strove for compassion, for mercy, for forgiveness? And what if we did this for everybody, including people who have harmed others?" Forman provides a litany of reform proposals to make the criminal system more compassionate and restorative). Howard Zehr, who aspires to a system where restorative practices are the norm and the legal or criminal justice system serves as an alternative to be drawn on when needed, also proposes the shift to a more restorative criminal justice system. See ZEHR, supra note 17, at 63. 
"What laws have been broken? Who did it? What do they deserve?"187 This line of inquiry essentially looks at the offender's conduct in a vacuum and leaves little room to consider gravity of harm, normative innocence, ${ }^{188}$ or concerns of disparate enforcement. ${ }^{189}$ It asks prosecutors - and by extension, police - to focus on crimes with no identifiable harm, thereby increasing the likelihood of unnecessary police interactions with citizens and a heavy reliance on police narratives in court. ${ }^{190}$ Prosecuting these victimless "public order" offenses diverts time and resources away from more serious misdemeanors and results in extraordinarily high numbers of convictions, despite a lack of demonstrable harm. ${ }^{191}$

A recent example of the type of case the retributive framework generates: An African-American man, Johnny Rush, was stopped by officers in Asheville, North Carolina for jaywalking across an empty street. ${ }^{192}$ After he attempted to walk away from the officers, he was chased, beaten, and repeatedly tased. ${ }^{193}$ Viewing the video of the incident causes a reasonable person to ask why two uniformed officers would bother stopping a man for crossing an empty street, as it is unclear what social harm they were trying to address. Yet, the

187. See ZEHR, supra note 17, at 63.

188. See Bowers, supra note 146, at 1678 (defining normative innocence as "conduct ... undeserving of communal condemnation, even if it is contrary to law").

189. K. Babe Howell has proposed that prosecutors should decline to prosecute low-level misdemeanor offenses where there is concern of racial disparity, based on their duties arising out of the ABA Standards and Prosecutor Professional Conduct. See Howell, supra note 148, at 287.

190. See Alexandra Natapoff, Misdemeanors, 85 S. CAL. L. REv. 1313, 1318 (describing the massive problem of the oversized misdemeanor system and its high potential for wrongful convictions as being most acute in the context of "high-volume arrest policies such as urban drug sweeps and zero-tolerance policing in which police are simultaneously enforcers and primary sources of evidence.").

191. See id, at 1321 (noting that in some jurisdictions as many as $40 \%$ of the petty offense or misdemeanor cases in the system may be driving with a suspended license charges); See also Howell, supra note 148, at 295. For example, in the state of Ohio, the following offenses are or can be misdemeanors: assault, OHIO REV. CODE $\S$ 2903.13 (2013), menacing by stalking, $\S 2903.211$, sexual imposition, $\S 2907.06$, riot, $\S 2917.03$, and domestic violence, $\S 2919.25$. Yet the same prosecutors responsible for pursuing justice in those cases may also be spending time on charges such as driving under suspension, $\S 4510.11$, and failure to comply with the order or signal of a police officer, $\S 2921.331$, as well as a plethora of even less serious traffic offenses.

192. See Meagan Flynn, 'I Can't Breathe': Asheville Police Video Shows White Officer Beating and Choking Black Jaywalking Suspect, WASH. Post (Apr. 3, 2018), https://www.washingtonpost.com/news/morning-mix/wp/2018/04/03/i-cantbreathe-asheville-police-video-shows-white-officer-beating-choking-blackjaywalking-suspect/?utm_term=.14e19a1d2326 [http://perma.cc/TKZ9-YA6D].

193. Id. 
retributive system does not ask those questions. It asks only whether jaywalking is a crime. ${ }^{194}$ There were no witnesses to this incident other than the officers and Rush. Were it not for the presence of body-worn cameras, a trial would have pitted the officers' word against Rush'sprecisely the kind of police-credibility trial described in Part II, in which the prosecutor would have to rely heavily, if not exclusively, on the credibility of the officer's narrative.

Scholars have proposed numerous ways and reasons to focus prosecutorial attention away from minor offenses. ${ }^{195}$ This proposal differs slightly by proposing that prosecutors specifically use restorative justice as the framework to guide their decision-making. Unlike retributive justice, restorative justice defines a crime by the created harm. ${ }^{196}$ Restorative practitioners ask: "Who has been hurt? What do they need? Whose obligations and responsibilities are these? What causes contributed to this?" 197 This method requires that the decision-maker consider more than just the apportionment of blame. In so doing, it resists the dehumanization that exists throughout much of the criminal system and its history, ultimately making it harder to weaponize against vulnerable populations than the retributive system has proven to be. 198 "Restorative justice asks stakeholders to look at crime through a fundamentally different lens. . . . This shift requires not only the reimagining of roles (and the norms for behavior associated with those roles) but also the reordering of priorities and restructuring of power." 199 If prosecutors took a more restorativebased approach to criminal justice, they would necessarily focus more

194. See Matt Apuzzo \& John Eligon, Department of Justice Reaches Agreement with Ferguson, N.Y. TIMES (Jan. 27, 2016), https://www.nytimes.com/ 2016/01/28/us/department-of-justice-reaches-agreement-with-ferguson.html [http://perma.cc/DLE5-3YY8] Part of the Ferguson Consent Decree was a repeal of the jaywalking ordinance, after it was made clear to the city that $95 \%$ of people arrested for jaywalking were African American, and that in the rare instance when the person arrested and charged with a similarly low-level offense was white, the chances of the case being dismissed were $68 \%$ higher. $I d$.

195. See, e.g., Bowers, supra note 153, at 1709; Howell, supra note 148; Natapoff, supra note 17, at 256.

196. Patrick Gerkin et al., Implementing Restorative Justice Under the Retributive Paradigm: A Pilot Program Case Study, SAgE OPEN 1 (2017), http://journals.sagepub.com/doi/pdf/10.1177/2158244017691562

[https://perma.cc/2685-5L92] ("The process begins with the realization that crime signifies injury.").

197. See ZEHR, supra note 17, at 21.

198. See generally ALEXANDER, supra note 71.

199. See Gerkin et al., supra note 196, at 8. 
on cases involving victims. ${ }^{200}$ This could decrease prosecutor complicity in police testilying by reducing the number of cases in which prosecutors rely exclusively on police testimony. By moving away from the use of common policing narratives, prosecutors could begin to lessen the ways in which the criminal system has discredited the narratives of marginalized communities. This may ultimately help those previously discredited narratives become more readily accepted in cases involving allegations of police violence.

Another reason to focus reform efforts here is that this change can be made immediately, without any major changes in the law. Incorporating restorative principles into the formal criminal justice system is not a new idea, nor is it outside the existing authority of prosecutor offices. ${ }^{201}$ The American prosecutor today has the power to shift the decision-making framework of the criminal system from retributive to restorative without a single legislative act. ${ }^{202} \mathrm{He}$ or she has the authority to exercise discretion in declining to pursue criminal charges, ${ }^{203}$ to develop alternatives to prosecution or conviction in individual or classes of cases, ${ }^{204}$ and to effect remedial action where inadequacies or injustices exist in the criminal system. ${ }^{205}$ Prosecutors right now have the ability to decline to pursue certain low-level crimes for any number of reasons, and many do. ${ }^{206}$ Finally, reform must include changes in the culture of prosecution because the power,

200. This is because the foundational question "Who has been harmed?" focuses on victims first, not perpetrators.

201. See Gerkin et al., supra note 196, at 8 (citing GERRY JOHNSTONE, Restorative Justice: Ideas, Values, Debates (2d. ed., 2011)).

202. See John F. Pfaff, Prosecutorial Guidelines, in 3 Reforming CRIMINAL Justice: Pretrial AND Trial Processes 101, 104 (Erik Luna ed., 2017) (explaining that the power and discretion of the American prosecutor is difficult to overstate). Moreover, the ABA Criminal Justice Standards for the Prosecution Function include in the standard regarding discretion in filing, declining, maintaining, and dismissing criminal charges; various restorative factors such as the extent or absence of harm, disproportionate collateral consequences, disparate treatment of other individuals; and the potential influence of any cultural, ethnic, socioeconomic, or other improper biases. See Criminal Justice Standards for the Prosecution Function § 3-1.2 (AM. BAR ASS'N 2015).

203. See § 3-1.2(b).

204. See § 3-1.2(e).

205. See § 3-1.2(d).

206. See Natapoff, supra note 17, at 258; see also Gonnerman, supra note 98 (noting that Rachael Rollins, a former federal prosecutor, ran and won the race for District Attorney on a platform promising to stop prosecuting drug possession, shoplifting, and other crimes, indicating that the cases that were not dismissed would be dealt with through community service, educational programs, or other means). 
discretion, and authority of prosecutors is so great that criminal justice reform realistically cannot take place without their involvement. ${ }^{207}$

\section{B. Electing Progressive Prosecutors Should Include Electing Prosecutors Committed to Restorative Justice}

While cultural changes can have a profound impact on office practices as well as the system as a whole, ${ }^{208}$ they require buy-in from top prosecutors. ${ }^{209}$ As more District Attorneys are elected on progressive platforms to decrease mass incarceration and reduce the disproportionate impact of the criminal system on poor people of color, more and more prosecution offices are undergoing major

207. Juleyka Lantigua-Williams, Are Prosecutors the Key to Justice Reform? Given Their Autonomy-Only If They Want to Be, ATlantic (May 18, 2016), https://www.theatlantic.com/politics/archive/2016/05/are-prosecutors-the-key-tojustice-reform/483252/ [http://perma.cc/FT28-9SE2] ("An Urban Institute report analyzed South Dakota's criminal-justice reforms and found that when certain low-level crimes were no longer eligible for lengthy sentences, prosecutions against crimes that were eligible for such sentences shot up. 'They noticed that DAs actually started increasing their charging in an effort to get around reform, ['] Pfaff said. He said that if states make it difficult to charge offenders with one type of crime, DAs will choose another option and use it widely. Sometimes, that results in even tougher sentences than the DAs might have originally sought. [']There is some evidence that DAs will, in the presence of reform laws, try to figure out ways['] around those reforms, Pfaff said. ['] They often have the ability to find ways to circumvent efforts at reform if they really want to.'”) (quoting John Pfaff).

208. See John Pfaff, Locked In: The True Causes of Mass INCARCERATION-AND HOW TO ACHIEVE REAL REFORM (2017) (“[I]t's worth noting not just how local the changes were, but how non-legal they were. The decline in drug incarcerations wasn't driven by the changes in the law, but by some combination of changing local crime rates and changing views of the local police and prosecutors about who to arrest and how harshly to charge them. It was more an attitudinal change, not a legal one.").

209. See id.; 3 Reforming Crim. Just.: Pretrial and Trial Processes 1, 103 (Erik Luna ed., 2017) To address the lack of buy-in, John Pfaff has suggested creating a set of guidelines for prosecutors that would govern discretionary decisions of charging, diversion, and plea-bargaining. Such guidelines are not a perfect solution but are one way to promote accuracy and consistency in decision-making and target issues such as implicit bias. See id. at 115. Perhaps the most insightful argument Pfaff makes is for asymmetry in the guidelines - making them binding when requiring leniency but only presumptive when imposing severity. See id. at 117. This could limit overcharging and the harsh retributive practices of "law and order" prosecutors who continue to hold a "tough on crime" mentality. See id. Perhaps more importantly, making the guidelines binding when imposing leniency creates the ability for prosecutors to pursue restorative resolutions to cases without fear of public reproach for being "soft on crime." 
cultural shifts. ${ }^{210}$ Newly elected progressive prosecutors have taken various steps to address the culture of prosecution upon taking office. Some have fired higher-level assistant prosecutors and replaced them with more like-minded attorneys or with newer attorneys less likely to resist progressive approaches. ${ }^{211}$ Many seek to create or strengthen their Conviction Integrity or Conviction Review Units to investigate claims of police or prosecutorial wrongdoing during the charging or trial process. ${ }^{212}$ Others move to eliminate cash bail to ensure fairness and reduce the concern that guilty pleas are predicated on an inability to make bail. ${ }^{213}$ Some have immediately ceased prosecuting certain offenses or promulgated policies for how to treat certain types of crimes. ${ }^{214}$ Some have made changes to their training practices, including hiring outside organizations such as Adam Foss's Prosecutor Impact to ensure that new prosecutors have an understanding of the lives of the people they are prosecuting as well as how issues of race, poverty, addiction, and mental illness intersect with the criminal system. ${ }^{215}$

210. See, e.g., David Alan Sklansky, The Changing Political Landscape for Elected Prosecutors, 14 OHIo St. J. CRIM. L. 647, 647, 667 (2017); see also Matt Ferner, Progressive Prosecutors Win Primaries in North Carolina, Huffington Post (May 8, 2018), https://www.huffingtonpost.com/entry/north-carolina-progressiveprosecutors_us_5af22ea3e4b0aab8a78a067e?ncid=engmodushpmg00000004 [http://perma.cc/EX8H-UVH3]; Ben Austen, In Philadelphia, a Progressive D.A. Tests the Power - and Learns the Limits - of His Office, N.Y. Times MAG. (Oct. 30, 2018), https://www.nytimes.com/2018/10/30/magazine/larry-krasner-philadelphiadistrict-attorney-progressive.html [http://perma.cc/Y8AJ-ZVE3] (“[B]eginning in 2013, when the late Ken Thompson unseated a 23-year incumbent in Brooklyn, voters have elected 30 reform-minded prosecutors, in municipalities as varied as Corpus Christi, Kansas City and San Francisco.”); Gonnerman, supra note 98.

211. See Gonnerman, supra note 98.

212. See id.

213. See id.

214. Shaun King, Philadelphia DA Larry Krasner Promised a Criminal Justice Revolution. He's Exceeding Expectations, INTERCEPT (Mar. 20, 2018, 3:59 PM), https://theintercept.com/2018/03/20/larry-krasner-philadelphia-da/

[http://perma.cc/8TQ3-9QYB] (discussing a five-page memorandum issued by Krasner shortly after taking office mandating that all line prosecutors decline charges of marijuana possession and prostitution).

215. See Matt Watkins, Prosecutor Power \#5, Adam Foss: Use Your Power Well, CTR. CT. InNOvAtion, https://www.courtinnovation.org/publications/adamfoss-podcast [https://perma.cc/6Q28-X68M] (last visited Mar. 4, 2019). 


\section{Training and Educating Progressive Prosecutors Can Support This Paradigmatic Shift}

To bring about such a paradigmatic shift, the way that law schools train and educate future prosecutors also needs to change. Most American law schools have defense clinics that allow students to practice as certified legal interns under the supervision of a clinical professor, usually representing indigent clients who would otherwise be represented by a public defender. These clinical experiences are invaluable for shaping new lawyers; they offer opportunities for law students to develop their understanding of lawyering and client representation, to begin to create their professional persona and sense of ethics, and to expose and critique the systems of power that target marginalized communities through criminal prosecution.

There are, comparatively speaking, relatively few similarly situated prosecution clinics. ${ }^{216}$ Instead, law students typically intern at a prosecutor's office under the supervision of a staff attorney. While this can be a tremendous opportunity for law students, it is not a comparable experience to a full criminal prosecution clinic. Staff attorney caseloads do not permit the type of hands-on supervision and in-depth feedback on student lawyering that a clinical professor is expected to provide. Externships at law schools may have a class seminar component but are typically not segregated by subject matter. This means that students in externship seminars cannot typically engage in case rounds - the seminal pedagogy of law clinics - due to confidentiality concerns. Case rounds give students the opportunity to seek advice from their classmates and professors on everything from

216. As of 2018, out of 203 ABA-approved law schools, thirty-six have prosecution clinics, but only nineteen appear to have an "in-house" clinic, as opposed to an externship agreement with a District Attorney Office supplemented by a seminar class. In contrast, 107 law schools have some form of a defense clinic (fourteen of those are "specialty" clinics focused on appeals, wrongful convictions, juvenile defense and death penalty work). Seventy-eight law schools have an "in-house" defense clinic, and approximately fifteen have an agreement with a criminal defense organization or public defender office offering an externship and associated seminar class. Information is on file with the author and available upon request. Note that there is an argument to be made, raised by the author's excellent research assistant Matthew Finston, that most law schools frame their clinic programs as services provided to the indigent community in order to increase access to justice, and perhaps prosecution clinics do not fit this model. But they should. Indigent communities are not only vastly overrepresented as defendants in the criminal system, but they are also vastly underrepresented as victims. A restorative-based, problem-solving approach to prosecution could aid law schools in achieving their mission to increase access to justice. 
the constitutionality of a search to the disclosure of discovery to trial theory, as well as to discuss their fears, beliefs, and concerns. Without a dedicated criminal justice curriculum, students may lack the opportunity to reflect on larger systemic issues of mass incarceration, the history of criminal jurisprudence, racial disparities in the criminal system, and prosecutorial ethics. ${ }^{217}$ These are conversations that law students are interested in having, yet they may not be the types of conversations that first or second-year prosecutors are able to engage in when they are trying to keep up with heavy caseloads and learning to navigate an entirely new world of judges, complainants, police officers, and supervisors.

Moreover, internships at District Attorney offices may unintentionally replicate some of the problems in the criminal system. Line prosecutors-particularly in misdemeanor court-have overburdened caseloads. They rarely have the time to conduct investigations, meaningfully vet witnesses, or work with community resources to find resolutions to cases that both restore victims and equip defendants not to recidivate. Defense attorneys approaching prosecutors at initial court hearings often find an attorney who has not had time to open the file, much less look into issues like Fourth Amendment violations, witness bias, or defendant mitigation, all of which should play a part in case disposition. Prosecutors in misdemeanor court, where most interns are assigned, are also heavily reliant on police officer narratives to make out their cases and often lack the institutional clout to challenge such narratives when they appear suspect. Student interns without a dedicated instructor are learning from these prosecutors and may be assuming that they are seeing best practices rather than triage.

A clinical setting can address some of this. Clinical students are typically assigned far fewer cases than first and second-year prosecutors or interns. This gives them the opportunity to investigate the police report for any potential Fourth Amendment violations or evidentiary problems. It affords them the time to speak and meet with potential witnesses to reveal any biases that may be informing their testimony, weaknesses that could undermine a trial, or - in the case of complainants - specific desired outcomes that could inform plea negotiations. ${ }^{218}$ It gives them the time and opportunity to build

217. This is not to mention experiential learning opportunities such as jail tours, police ride-alongs, and guest lectures by practitioners and local experts.

218. Consider, for example, the complainant who wants only restitution for a theft or criminal damaging, and who has no interest in saddling the defendant with a criminal charge. 
meaningful relationships with complainants, allowing them to create solutions that take complainants' stated needs into account, as well as to ensure they are heard and respected by the system. This can lead to more effective and just resolutions earlier in the life of a case-saving the system, the defendant, and the complainant or witness time, money, and hardship. Finally, law school clinics may have fewer institutional concerns when it comes to maintaining police relationships because handling fewer cases makes them less reliant on those relationships. This may allow law students in a clinic to feel more able to withdraw charges where they believe police have violated the defendant's constitutional rights or to investigate more thoroughly police stories that invoke troublesome narratives.

One concern that may be raised in response is that law students who do eventually become prosecutors will not be practicing under these conditions. That should not be dissuasive. After all, defense clinic students handle relatively few cases over the course of the semester compared to the massive caseloads of public defenders. Having the opportunity to learn under the best possible conditions first is valuable. The purpose of a law school clinic is not to replicate the hardships of practicing in the real world. It is to provide students with as solid a foundation as possible upon which to build their skills, allowing them to approach their work with insight, empathy, and an understanding of how each individual case fits into the larger criminal system. The goal of the clinic is to ensure that students learn skills that they will continue to draw upon throughout their careers, even under the more adverse practice conditions they will face in the real, and troubled, world. ${ }^{219}$ Increasing the offerings of law school prosecution clinics to teach restorative-based decision-making practices may therefore be a part of the solution.

In order to facilitate a shift from an Adversary or Case-Processor framework of prosecution to a Problem-Solver framework,

219. One can also hope that increasing the offerings of prosecution clinics in law schools could attract a more diverse set of new lawyers to prosecution. As of $2014,95 \%$ of elected prosecutors in the United States were white, and $83 \%$ were men. Amita Kelly, Does It Matter That 95\% of Elected Prosecutors Are White? NPR, https://www.npr.org/sections/itsallpolitics/2015/07/08/420913118/does-it-

matter-that-95-of-elected-prosecutors-are-white [http://perma.cc/7SQ3-78RH] (citing a report by the Reflective Democracy Campaign). Increasing the diversity of prosecutors could help to increase the cultural humility of prosecution offices and mitigate some of the implicit biases exhibited in discretionary decisions. CRIMINAL Justice Standards for the Prosecution Function $§ 3-2.3(d)$ (Am. Bar Ass'N 2015). ("[S]pecial effort should be made to recruit women and minority prosecutors."). 
prosecution offices should embrace restorative-driven decisionmaking within the retributive American criminal system. By supporting and electing progressive prosecutors whose campaigns include a commitment to restorative practices, voters can shift the needle from a solely retributive "law and order" approach to prosecution to a more restorative one. This may in turn reduce prosecutor dependency on police officers and allow for a more robust policing of the police. Law schools should create more offerings specifically for prosecution-minded law students that allow them to engage in restorative-based practices in a clinical setting. Progressive prosecution offices should continue this work by teaching these values in initial trainings like those run by Prosecutor Impact ${ }^{220}$ and by reinforcing these values through office culture by establishing robust Conviction Integrity Units and Restorative Justice Units and using means other than conviction rates to measure prosecutor success. ${ }^{221}$

\section{CONCLUSION}

Accountability through criminal charges is fundamental to the rule of law.222 Persistent acquittals of officers like Jason Stockley and Betty Shelby undermine citizens' belief in the rule of law ${ }^{223}$ because they lay bare what many see as a double standard in the treatment of police defendants versus defendants of color. ${ }^{224}$ More robust prosecutions of police are necessary in order to hold individuals accountable and send the message to society that systemic police violence against people of color is unacceptable. This message is necessary to address the culture of impunity that has surrounded

220. See generally, e.g., ProseCUTOR IMPACt, https://prosecutorimpact.com/ [https://perma.cc/67KH-GT22] (last visited Mar. 4, 2019).

221. The Brennan Center for Justice, Fair and Just Prosecution, \& The Justice Collaborative, 21 Principles for the 21 st Century Prosecutor (2018), https://www.brennancenter.org/sites/default/files/publications/FJP_21Principles_FI

NAL.pdf [http://perma.cc/LXE2-A5NV] (establishing a set of practical steps to make prosecution more just including the creation of Conviction Review Units to scrutinize past convictions for "unjust practices, faulty evidence, or bias" and promoting restorative justice programs to meaningfully respond to the harm caused by criminal acts).

222. See ZeHR, supra note 17, at 22 .

223. Greensboro TRC Report, supra note 1, at 16. ("We find one of the most unsettling legacies of the shootings is the disconnect between what seems to be a common sense assessment of wrongdoing and the verdicts in the two criminal trials. When people see the shootings with their own eyes in the video footage, then know that the trials led to acquittals, it undermines their confidence in the legal system.").

224. Lee \& Ifill, supra note 7. 
racially motivated police violence for centuries. Prosecutors currently face an uphill battle seeking convictions against police officers due to their long-standing dependency on police as witnesses and their routine complicity with officers falsifying testimony. Decreasing reliance on officer narratives by moving away from a purely retributive approach to criminal justice in favor of more restorativebased practices could alleviate some of these challenges.

This shift to more restorative decision-making can be brought about through top-down cultural changes in prosecution offices, as well as through greater investment in training and educating future prosecutors while in law school. Shifting to a restorative-based practice will not scrub implicit bias from the criminal system, nor directly address the racial profiling and disproportionate policing that goes on in low-income neighborhoods of color. As argued in Part II, the criminal system - with its focus on individual cases and individual harm - is ill-equipped to unearth and combat these larger systemic issues. However, effectively holding police officers accountable for crimes committed - particularly those against individuals of color-is a necessary predicate for concurrent restorative practices in the informal justice system to surface and confront larger systemic and historical truths. ${ }^{225}$

Given the increasingly divisive and hateful rhetoric that has characterized much of American life for the past few years, there will no doubt be a time in the near future when Americans will need reconciliation. But reconciliation cannot take place while injustices sought to be addressed are ongoing. In order to create a foundation upon which reconciliation can take place, perpetrators - particularly those acting under the authority of the State-must be held accountable for their actions. Prosecutors, who have been called "the gatekeeper of America's justice system," ${ }^{226}$ have a large and difficult role to play in that process. The proposal laid out in this Article works in concert with numerous other proposals as a way to begin.

225. 1 Truth \& Reconciliation Commission, South Africa Report 11112 (1998), http://www.justice.gov.za/trc/report/finalreport/Volume\%201.pdf [https://perma.cc/8YL5-NWBZ] ("The information in the hands of the [TRC] made it impossible to claim, for example, that: the practice of torture by the state security forces was not systematic and widespread; that only a few 'rotten eggs' or 'bad apples' committed gross violations of Human rights . . . ."); see also 5 TRUTH \& RECONCILIATION COMMISSION, SOUTH AFRICA REPORT 435 (1998), http://www.justice.gov.za/trc/report/finalreport/Volume5.pdf [https://perma.cc/8X3F-EVTX].

226. Austen, supra note 210 (quoting Shaun King). 